\title{
Shelf versus traditional seasoned equity offerings: the impact of potential short selling
}

DOI:

$10.1017 /$ S0022109018000911

\section{Document Version}

Accepted author manuscript

Link to publication record in Manchester Research Explorer

\section{Citation for published version (APA):}

Dutordoir, M., Strong, N., \& Sun, P. (2019). Shelf versus traditional seasoned equity offerings: the impact of potential short selling. Journal of Financial and Quantitative Analysis, 54(3), 1285-1311.

https://doi.org/10.1017/S0022109018000911

\section{Published in:}

Journal of Financial and Quantitative Analysis

\section{Citing this paper}

Please note that where the full-text provided on Manchester Research Explorer is the Author Accepted Manuscript or Proof version this may differ from the final Published version. If citing, it is advised that you check and use the publisher's definitive version.

\section{General rights}

Copyright and moral rights for the publications made accessible in the Research Explorer are retained by the authors and/or other copyright owners and it is a condition of accessing publications that users recognise and abide by the legal requirements associated with these rights.

\section{Takedown policy}

If you believe that this document breaches copyright please refer to the University of Manchester's Takedown Procedures [http://man.ac.uk/04Y6Bo] or contact uml.scholarlycommunications@manchester.ac.uk providing relevant details, so we can investigate your claim.

\section{OPEN ACCESS}




\title{
Shelf versus traditional seasoned equity offerings: The impact of potential short selling
}

\author{
Marie Dutordoir \\ Norman Strong* \\ Ping Sun ${ }^{1,2}$
}

January 2018

\footnotetext{
* Corresponding author. Address: Alliance Manchester Business School, Manchester M15 6PB, United Kingdom. Email: norman.strong@manchester.ac.uk. Tel.: +44 (0) 1612754006.

${ }^{1}$ We thank Tyler Henry, Jennifer Koski, Inmoo Lee, Patrick Pollmann, Melissa Porras Prado, Patrick Verwijmeren, Fangming Xu, participants at the 2016 FMA European Conference, the 2016 European Finance Association Annual Meeting, and the $5^{\text {th }}$ Annual Corporate Finance Conference, and an anonymous referee for their helpful comments and suggestions.

2 Alliance Manchester Business School, United Kingdom. Email addresses: marie.dutordoir@manchester.ac.uk (M. Dutordoir), ping.sun@postgrad.mbs.ac.uk (P. Sun).
} 


\title{
Shelf versus traditional seasoned equity offerings: The impact of potential short selling
}

\begin{abstract}
Traditional SEOs elicit short selling from traders trying to increase offering discounts. Such short selling is more difficult for shelf offerings, as the time between their announcement and issuance tends to be shorter. We predict and find that firms with higher short-selling potential (SSP) are more likely to choose shelf over traditional SEOs. This result is robust to alternative proxies for SSP and other sensitivity tests. Further analysis suggests that shelf issuers aim to mitigate the threat of manipulative short selling. Our findings add to a growing literature showing that short selling has a real impact on corporate finance decisions.
\end{abstract}




\section{Introduction}

In the U.S., firms can register and conduct public seasoned equity offerings (SEOs) through traditional or shelf offerings. In a traditional offering, firms file a registration for each security issue. In contrast, a shelf registration allows qualified firms to file a single all-encompassing registration covering all security offerings in the following three years. ${ }^{3}$ Since the early 1990 s, shelf offerings have grown dramatically in popularity (Autore et al. 2008). However, despite the increasing use of shelf offerings, few studies have investigated firms' choice between shelf and traditional offerings.

In this paper, we test the impact of anticipated short selling on firms' likelihood of choosing a shelf-registered over a traditional SEO. Our work draws on Gerard and Nanda's (1993) theory of SEO underpricing. In their model, manipulative short sellers disguise their private information through heavy short selling between the announcement and issue dates of an SEO, thereby reducing the informativeness of the pre-issue order flow and increasing offering discounts. Manipulative short selling is more difficult for shelf than for traditional SEOs. The reason is that, while traditional SEOs tend to have several weeks between their announcement and issue dates, shelf registrations allow qualified firms to offer equity without additional regulatory intervention, resulting in little or no advance notice of their actual issue (Bethel and Krigman 2008). As a result, manipulative short sellers face restrictions in establishing their positions before shelf SEOs, particularly because the SEC imposes strong constraints on manipulative short selling

\footnotetext{
3 The SEC extended shelf registration coverage to three years, from two years, in 2005 . Table IA1 of the Internet Appendix explains shelf eligibility criteria in detail.
} 
during the five trading days before SEO issue dates. We therefore predict that firms whose stocks are more likely to be shorted are more likely to opt for a shelf over a traditional offering, in order to mitigate the impact of manipulative short selling on their offering discounts. Following Massa et al. (2015), we adopt the term 'short-selling potential' (SSP) to denote anticipated short selling of individual firms.

We test our hypothesis on a sample of U.S. SEOs between 2004 and 2014. Consistent with prior empirical work (Saffi and Sigurdsson 2011; Massa et al. 2015; Prado et al. 2016), we use the ex-ante lending supply of firms' shares as our main proxy for their SSP. A high lending supply indicates fewer short-selling constraints and hence a higher SSP, as investors incur lower costs of locating shares for borrowing (Duffie et al. 2002). As predicted, we find that lending supply has a positive impact on the probability of choosing a shelf offering. Its impact is both statistically and economically significant. Our analysis controls for firm- and offer-specific SEO method determinants used in previous studies (Autore et al. 2008; Bethel and Krigman 2008), and for changes in short-selling regulation over the sample period.

To test the robustness of our baseline findings, we use alternative SSP proxies from the literature (D’Avolio 2002; Cohen et al. 2007; Saffi and Sigurdsson 2011; Massa et al. 2015), as well as an index that aggregates our proxies. We again find that firms with a higher SSP are more likely to choose shelf over traditional SEOs. Results using daily short sales data confirm the hypothesis that firms use shelf registrations to avoid short selling.

The positive impact of SSP on the likelihood of choosing shelf over traditional SEOs is robust to controlling for standard measures of firm overvaluation and to restricting the sample to 
SEOs that are unlikely to be motivated by overvalued equity. These results suggest that SSP is not merely associated with SEO method choice through its association with firm overvaluation. Moreover, among the shelf SEOs, we find that issuers with higher SSP are more likely to complete their offering within the short-selling restricted period of five trading days. This result further corroborates that our baseline finding is not due to the influence of unobservable differences between shelf and traditional issuers.

Alongside manipulative trading, short selling between SEO announcement and issue dates can reflect trading by pessimistic investors who interpret an SEO as a negative signal about firm value (Kim and Verrecchia 1994; Henry and Koski 2010). We verify the importance of informed versus manipulative short selling in driving firms' SEO method choice by examining offering discounts. Manipulative short selling leads to higher price uncertainty by obscuring the information incorporated into secondary order flows, while the opposite holds for informed short selling (Kim and Shin 2004). Thus, to the extent that shelf offerings curb manipulative (informed) short selling, they should reduce (increase) offering discounts. We find evidence of higher counterfactual offering discounts for shelf issuers had they chosen a traditional offering instead, suggesting that firms choose shelf SEOs in order to reduce the threat of manipulative rather than informed short selling.

Our study extends the literature through three contributions. First, we add to several recent papers that examine short sellers' investment activities in the context of mergers and acquisitions (Mitchell et al. 2004), convertible bond issuance (De Jong et al. 2011), and corporate investment (Grullon et al. 2015). We provide evidence that security issuers adjust their SEO method to 
impede short selling, further corroborating the view that firms consider short-selling activity when making corporate finance decisions.

Second, we contribute to the literature on the motives and costs of different SEO methods. Denis (1991) finds that firms with more asymmetric information about their true value are more likely to choose traditional over shelf SEOs, consistent with a lack of underwriter certification associated with the shelf procedure. Bethel and Krigman (2008) also document that issuers with high asymmetric information tend to prefer traditional over shelf offerings, as the latter result in more negative combined market reactions around their filing and takedown dates. Autore et al. (2008) find a positive relation between firms' stock return volatility and their likelihood of choosing a shelf over a traditional SEO. They argue that issuers with volatile stock returns value the flexibility associated with the shelf procedure. Gao and Ritter (2010) examine firms' motives for choosing accelerated shelf-registered equity offerings and find that the pre-issue elasticity of demand for a firm's stock is a key determinant of this decision. Gustafson (2017) focuses on the motives for overnight SEOs, which constitute a subset of shelf issues, but does not examine the role of (potential) short selling. To our knowledge, we are the first to test the effect of the threat of short selling on firms' choice between shelf and traditional SEOs.

Third, we contribute to the literature on short selling before SEOs. Previous studies mainly focus on the relation between manipulative short selling between SEO announcement and issue dates and SEO discounts (Safieddine and Wilhelm 1996; Corwin 2003; Kim and Shin 2004; 
Singal and Xu 2005; Henry and Koski 2010; Autore 2011; Autore and Gehy 2013). ${ }^{4}$ Most closely related to our study, Henry and Koski (2010) find that higher pre-issue short selling is associated with larger offering discounts for traditional offerings, but not for shelf offerings. They suggest that firms may use shelf offerings to avoid the costs of manipulative short selling associated with an SEO, but do not formally test this claim. Deshmukh et al. (2017) focus on informed rather than manipulative short selling before SEOs. They document higher short interest before shelf than before traditional SEO announcements, consistent with short sellers' ability to identify opportunistic market timers among shelf issuers. Their work differs from ours by focusing on pre-announcement short sales, which firms cannot reduce through their SEO method choice. In contrast, we focus on short selling occurring between SEO announcement and issue dates, our key hypothesis being that firms choose shelf offerings to mitigate this type of short selling.

The remainder of the paper continues as follows. Section 2 discusses the relevant theory guiding our main hypothesis. Section 3 describes the sample. Section 4 presents baseline results on the determinants of the SEO method choice as well as robustness tests of these results. Section 5 investigates whether shelf issuers try to avoid manipulative or informed short selling. Section 6 concludes the paper.

\footnotetext{
${ }^{4}$ Safieddine and Wilhelm (1996) find a reduction in short selling and issue discounts after the introduction of SEC Rule 10b-21. Corwin (2003), Kim and Shin (2004), and Singal and Xu (2005) find that Rule 10b-21 led to an unintended increase in SEO issue discounts. Henry and Koski (2010) provide evidence of a positive relation between SEO discounts and pre-issue short selling after the introduction of Rule 105. Autore (2011) analyzes discounts for shelf offers following an extension of Rule 10b-21 and finds that pre-issue short sales constraints did not increase discounts for shelf offers. Autore and Gehy (2013) find that the 2007 amendment to strengthen Rule 105 led to an unintended increase in issue discounts of overnight offerings.
} 


\section{Theoretical background and testable hypothesis}

Our main hypothesis examines the impact of firms' short-selling potential on their choice between shelf and traditional SEOs. We now motivate this hypothesis.

To ensure the success of an SEO and compensate new investors for the winner's curse, firms typically offer new shares at a discount to the pre-issue stock price (Asquith and Mullins 1986; Masulis and Korwar 1986; Rock 1986; Altinkiliç and Hansen 2003). This discount is a component of SEO issuance costs, together with underwriter fees and asymmetric information-induced stock price declines around the offering announcement (Autore et al. 2008; Bethel and Krigman 2008; Huang and Zhang 2011).

Gerard and Nanda (1993) develop a theoretical model showing that manipulative short-selling activity may affect SEO discounts. In their model, SEO discounts are higher when secondary order flows are less informative, but do not depend on the quantity of submitted bids. This setting offers the potential for manipulation due to the interaction between secondary market trading before the offering and the pricing of the offering. In particular, manipulative traders may try to reduce the informativeness of the secondary order flow by selling shares before the SEO, profiting subsequently from lower prices in the offering. Even if these strategic traders have favorable information, they may still want to sell short in the secondary market to conceal their positive information in anticipation of the offering. Such manipulative short selling is profitable as long as traders can recuperate their losses by purchasing newly issued shares at a discount in the SEO. 
To address concerns regarding manipulative short selling before SEOs, the SEC prohibits investors who have shorted an issuer's stock in the five trading days before an offering from participating in the offering. This regulation should be more effective at curbing manipulative short selling for shelf than for traditional SEOs. The reason is as follows. A major feature of shelf offerings is that, once the SEC approves the core prospectus and registration statements, firms face no additional disclosure requirements or regulatory delays when issuing securities (Bethel and Krigman 2008). In contrast, for traditional SEOs, the SEC's review of prospectuses and registration documents can take weeks or even months to complete. As a result, the announcement date of a traditional offering is typically several weeks before the issue date. For example, in our SEO sample, the average number of trading days between the announcement and issue dates of traditional offerings is 31.8 , versus 2.8 for shelf offerings. Moreover, while $99.29 \%$ of traditional offerings have more than five trading days between announcement and issuance, this percentage is $12.34 \%$ for shelf offerings. ${ }^{5}$ Given that the interval between announcement and issuance tends to be so short for shelf offerings, it is difficult for manipulative short sellers to set up their positions. This feature of shelf offerings should be more attractive for firms that short sellers are more likely to target, i.e., firms with a high short-selling potential (SSP). We thus form the following hypothesis:

Firms with higher short-selling potential are more likely to choose a shelf over a traditional SEO.

\footnotetext{
5 Figure 1 shows the distribution of trading days between SEO announcement and issue dates for our sample of shelf and traditional offerings.
} 


\section{Data and SEO sample characteristics}

\subsection{Sample construction}

Our sample consists of U.S. seasoned common stock offerings from the Securities Data Corporation (SDC) Global New Issues database between September 2004 and December 2014. We start our sample in September 2004 because the SEC harmonized restrictions on short selling for shelf and traditional offerings in that month. Before September 2004, the relevant SEC Rule 105 did not cover shelf offerings. We adopt standard SDC data screens to exclude Initial Public Offerings (IPOs), rights offerings, unit issues, closed-end funds, Real Estate Investment Trusts (REITs), simultaneous international offerings, offerings by non-U.S. firms, and purely secondary offerings from our search. We obtain an initial data set of 3,005 SEOs, of which 2,329 are shelf and 676 are traditional offerings.

We further restrict the sample by imposing three standard requirements. First, we require that the issuer's stock is listed on the New York Stock Exchange (NYSE), NYSE MKT (previously AMEX), or NASDAQ. Second, the issuer must have at least 30 days of pre-announcement stock return data available on the Center for Research in Security Prices (CRSP) database, and accounting data for the fiscal year end preceding the offering announcement date available on Compustat. Third, the issuer's stock price the day before the announcement must be higher than $\$ 5$, as stocks with prices under $\$ 5$ are difficult to short (D’Avolio 2002). Imposing these criteria reduces the sample to 1,978 SEOs, of which 1,519 are shelf and 459 are traditional offerings. 
In a next step, we remove traditional equity offerings by firms that do not qualify for shelf-registered common equity offerings, to ensure that characteristics related to shelf eligibility do not drive our results. Table IA1 of the Internet Appendix provides a detailed description of relevant SEC regulation regarding shelf eligibility. The SEC's first eligibility criterion sets the public float threshold to qualify for shelf registration at $\$ 75$ million (Federal Register 1992). Public float represents the aggregate value of the non-voting and voting common equity held by parties that are not corporate insiders (SEC 2017a). It is, by construction, never higher than a firm's market value. We therefore first remove traditional issuers with a market value from CRSP below the $\$ 75$ million threshold. This eliminates 31 traditional SEOs from the sample. In a second step, we verify whether the remaining traditional issuers fulfil the public float size requirement. Consistent with the approach in Gustafson and Iliev (2017), we hand-collect traditional issuers' public float information reported closest prior to the SEO announcement date from their 10-K filings obtained through EDGAR. This exercise identifies 39 further traditional SEOs by firms with a public float falling below the $\$ 75$ million threshold. Since the end of 2007 , however, the SEC allows issuers with a public float falling below the $\$ 75$ million threshold to use shelf registrations when they meet certain conditions that Table IA1 of the Internet Appendix (SEC 2007b; SEC 2017b) outlines. Among the traditional SEOs by firms that have a public float below the threshold and are issued after 2007, we identify two issuers that fulfil these conditions. We keep the two SEOs by these two firms in the sample, and remove the remaining 68 (i.e., 31 plus 39 minus 2) non-qualifying traditional offerings. 
The SEC's second shelf eligibility criterion pertains to the non-violation of certain dividend and debt-related payments. Using screening tools in S\&P Capital IQ, we identify that no issuers violated this criterion. Final relevant shelf eligibility criteria relate to firms' securities listing status and filing history. As our sample is restricted to companies listed on major U.S. stock exchanges, we assume that all our traditional issuers satisfy the SEC's listing status requirement. We check whether there are any traditional issuers in the remaining sample with IPOs within 12 months of their SEO, using IPO year information from Compustat. We find this is not the case, suggesting that these firms fulfil the SEC's filing requirements. Thus, in total, imposing shelf eligibility criteria gives us a sample of 1,910 SEOs, of which 1,519 are shelf and 391 are traditional offerings.

We then require that issuing firms have equity lending data available from Markit (formerly DataExplorers). This reduces the sample by a further 33 offerings, specifically 18 shelf and 15 traditional SEOs. Finally, as the SDC sometimes misclassifies shelf as traditional offerings (Gao and Ritter 2010), we manually check all the traditional offerings in our sample. We identify 96 offerings that EDGAR classifies as shelf offerings, and reclassify them accordingly (we also manually verify and find that there are no classification mistakes within the shelf offerings). Our final sample therefore comprises 1,877 SEOs, of which 1,597 are shelf and 280 are traditional offerings.

In a next step, we retrieve the announcement and issue dates of our sample offerings from the SDC. Figure 2 illustrates the average timeline of shelf and traditional offerings for our sample. For traditional offerings, we use the SDC filing date as the offering announcement date, 
in line with Duca et al. (2012). The filing date represents the date on which a firm first files its offering registration with the SEC. Many shelf registrations, however, never lead to an actual security offering, or only lead to a security offering after several years (Autore et al. 2008). For shelf offerings, we therefore use the SDC launch date instead of the filing date as the offering announcement date. The launch date is the date on which a firm first files the actual offering with the SEC and the market learns about the offering (SDC 2016).

Issue dates stated in financial databases are often miss-specified for offerings occurring after the close of trading (Lease et al. 1991). To identify the appropriate issue date, we apply a volume-based issue date correction in line with previous studies (Saffiedine and Wilhelm 1996; Corwin 2003; Henry and Koski 2010). We assign the issue date as the trading day following the SDC issue date if trading volume on this day is more than twice the volume on the SDC issue date and more than twice the average daily volume during the prior 250 trading days. This correction changes $58.27 \%$ of the SDC issue dates.

Table 1 reports the number and total proceeds of shelf and traditional SEOs over 2004-2014. The number and proceeds of shelf offerings declines slightly relative to traditional offerings over the first two years of our sample period, with this trend reversing in 2007. Total proceeds exhibit a similar trend. Over the entire sample period, shelf SEOs constitute $85 \%$ of total SEOs in terms of offering numbers, and $92 \%$ in terms of offering proceeds. 


\subsection{Measuring short-selling potential}

Consistent with prior literature, we define lending supply as the dollar value of shares available for lending on a given day scaled by a firm's market capitalization on the same day (Saffi and Sigurdsson 2011; Massa et al. 2015; Prado et al. 2016). We obtain equity lending data from Markit. The data are available at a weekly frequency from July 2004 to June 2006 and at a daily frequency for the remainder of the sample period. We measure Lendable as the average

lending supply in the three months ending one month before the offering announcement date. ${ }^{6}$ The mean (median) value of Lendable is $0.151(0.139)$. These values are close to the values in Prado et al. (2016).

\subsection{Firm and offer characteristics}

To disentangle the effect of anticipated short selling from firm- and offer-specific characteristics, we include a range of control variables suggested by previous studies of SEO method choice (Autore et al. 2008; Bethel and Krigman 2008). Firms with lower levels of asymmetric information have less need for the additional certification associated with the traditional offer method, and are therefore more likely to choose shelf offerings (Denis 1991; Bethel and Krigman 2008). We include bid-ask spread (BAS) and dispersion in analyst earnings-per-share (EPS) forecasts (Dispersion) as standard information asymmetry proxies (Bethel and Krigman 2008; Gomes and Phillips 2012). Dispersion is missing for a substantial number of observations (271 in total). To avoid losing these observations, we create a dummy

\footnotetext{
${ }^{6}$ The Appendix gives detailed definitions of all the variables in our study and their data sources.
} 
variable equal to one for observations with missing analyst forecast data, consistent with the approach of Bethel and Krigman (2008). ${ }^{7}$ We also include a variable capturing the number of analysts following the firm (Analyst). Analysts' information-production services may have a higher added value for firms with more severe information problems, leading to a positive association between analyst following and the level of information asymmetry (Maskara and Mullineaux 2011). As more analysts cover a firm, however, the level of asymmetric information is likely to fall (Bethel and Krigman 2008). We thus have no clear expectation for the impact of this variable on the likelihood of firms choosing a shelf over a traditional SEO.

We include three variables capturing potential market timing motives for shelf SEOs. Autore et al. (2008) argue that firms value the real option to defer or abandon an equity issue associated with a shelf registration. The value of this real option should be higher for firms with more volatile stock returns (Bethel and Krigman 2008), as captured by Volatility. We also include the pre-announcement stock run-up (Runup) and industry-adjusted market to book ratio (AdjMTB) to capture pre-announcement stock overvaluation. On the one hand, lower pre-announcement stock valuation may reduce the market's perception that opportunistic market timing motivates shelf offerings, resulting in less need for the additional certification associated with traditional offerings (Autore et al. 2008). On the other hand, firms with overvalued equity might value the timing flexibility associated with shelf offerings, even at the cost of incurring a market penalty (Deshmukh et al. 2017). The market to book ratio may also proxy for investment opportunities,

\footnotetext{
${ }^{7}$ In an unreported analysis, we obtain similar SEO method choice results when we only include observations with non-missing values for Dispersion.
} 
with no clear prediction for its impact on SEO choice (Bethel and Krigman 2008). Thus, overall, we have no clear expectation for the effects of these two proxies.

We include five additional firm-specific control variables suggested by studies of SEO method choice (Autore et al. 2008; Bethel and Krigman 2008). A priori, we have no clear expectation for the direction of their impact on the shelf versus traditional SEO choice. We control for firm size (LnTA), which proxies for a range of firm characteristics (Bethel and Krigman 2008), including as an inverse proxy for asymmetric information. We include trading volume (Turnover) as a measure of liquidity. We further control for firms' debt ratio (Leverage), which captures their ability to access debt financing rather than having to rely on common equity (Galai and Masulis 1976), and for free cash flow (FCF). We include a NYSE dummy variable to capture any differences across stock markets affecting SEO method choice.

Finally, we control for a number of offer characteristics. First, we include the size of the offering proceeds relative to firm size (RelOfrSize). On the one hand, larger offering sizes send a stronger signal of overvaluation (Krasker 1986), which might increase the added value of the stronger certification associated with traditional offerings. On the other hand, overvalued firms using shelf issues as a market timing device might want to increase the size of their offer to fully exploit their overvaluation, leading to a positive association between offer sizes and the likelihood of a shelf offering. Second, we control for the number of SEOs since the firm's IPO, using a Sequence dummy variable. Issuers may require less certification for SEOs occurring later in a sequence of SEOs (Autore et al. 2008). Third, we include a dummy variable equal to one for SEOs with a portion of shares offered by existing shareholders (Secondary). Investors are more 
likely to perceive such SEOs as sending an overvaluation signal (Bortolotti et al. 2008), which could make the added certification value of the traditional offering method more valuable.

Table 2, panel A reports mean and median values of our key variable of interest, Lendable, as well as of the firm- and offer-specific control variables, by SEO method. A plus (minus) sign next to a variable name indicates that we expect it to be higher (lower) for shelf than for traditional SEOs. As our main hypothesis predicts, we find higher Lendable values for shelf offerings. In terms of control variables, we find smaller BAS and Dispersion for shelf offerings, as predicted. We also find larger Analyst values for shelf offerings, consistent with analyst following proxying inversely for information asymmetry. For market timing proxies, differences in average Volatility and Runup are insignificant, while industry-adjusted market to book ratios $(A d j M T B)$ are significantly lower for shelf offerings. Regarding the other firm-specific control variables, for which we have no clear predictions, we find that shelf issuers have a larger firm size (LnTA), Turnover, and Leverage, smaller free cash flows (FCF), and are more likely to be listed on the NYSE. Regarding the offer-specific control variables, we find that shelf issuers have smaller relative offer sizes (RelOfrSize), a higher Sequence value (consistent with our prediction), and a lower likelihood of including a Secondary portion (consistent with our prediction). We conclude that shelf and traditional offerings differ on a range of firm- and offer-specific dimensions, suggesting the need to control for these variables in a multivariate analysis.

Table 2, panel B reports pairwise Pearson correlations between Lendable and the control variables. Correlations are highest with Analyst $(0.45, p$-value $<0.01)$ and LnTA $(0.44, p$-value $<$ 
0.01). Other pairwise correlations between Lendable and control variables are substantially lower in magnitude, indicating that Lendable does not act as a near perfect proxy for a firm or offer characteristic driving the SEO method choice.

\section{The impact of potential short selling on the SEO method choice}

This section first presents our baseline result on the impact of SSP on firms' likelihood of choosing shelf over traditional SEOs. We then provide and discuss several tests examining the robustness of our main result.

\subsection{Baseline result}

We use a logistic regression to model the determinants of the SEO method choice. The dependent variable equals one for shelf offerings and zero for traditional offerings. Lendable is the key independent variable of interest. In addition to control variables discussed in Section 3.3, we include year and industry fixed effects. Industry effects are based on the Fama-French 12-industry classification (Fama and French 1997).

Table 3, column (1) reports the regression estimates. Lendable has a positive impact on the probability of choosing shelf offerings, consistent with the hypothesis that issuers with a higher SSP prefer a shelf to a traditional offering. In terms of economic significance, a one standard deviation increase in Lendable, when all independent variables are at their mean values, increases the probability of choosing a shelf offering by $4.52 \%$. As this compares with an already very high unconditional probability of choosing a shelf offering (85\%), we follow Gao and Ritter (2010) and calculate the economic impact of Lendable when it is in a region of greater sensitivity, 
i.e., its $25^{\text {th }}$ percentile. ${ }^{8}$ The resulting marginal effect is a stronger $7.89 \%$. Regarding control variables, we obtain a negative impact for information asymmetry proxies BAS and Dispersion, consistent with Bethel and Krigman (2008). In line with Autore et al. (2008), we find a positive impact of Volatility. Inconsistent with these authors, but in line with the view that overvaluation increases firms' likelihood of opting for shelf SEOs, we find a positive impact for Runup. We further find a (weak) positive impact of Leverage, a negative impact of FCF, and a positive impact of NYSE, consistent with Bethel and Krigman (2008). Regarding the offer-specific control variables, we find a negative impact for relative offer size (RelOfrSize), in line with our prediction that the added value of traditional offerings might be higher for larger offering sizes (Krasker 1986). We find a positive impact for Sequence, consistent with Autore et al. (2008), and a negative impact for Secondary, consistent with our prediction. In an unreported robustness test, we obtain similar findings for the control variables if we exclude Lendable from the regression. ${ }^{9}$

We conclude that the positive impact of Lendable withstands the inclusion of a wide set of control variables suggested by the literature. In the remainder of this section, we discuss several robustness tests of our main result.

\footnotetext{
${ }^{8}$ Also in line with Gao and Ritter (2010), we hold other variables at their $25^{\text {th }}$ or $75^{\text {th }}$ percentile value depending on whether they have a positive or negative coefficient in Table 3, column (1).

9 The insignificant impact of firm size in Table 3 contrasts with Autore et al.'s (2008) and Bethel and Krigman's (2008) findings of a higher likelihood of shelf SEOs for larger companies. The difference is not due to including Lendable in our model, as LnTA remains insignificant when we exclude Lendable. The difference in findings may be partly due to changes in shelf eligibility criteria between our research window and that of previous studies. For example, Autore et al.'s (2008) sample starts in 1990, implying that part of their sample offerings fall under the former SEC requirement of having a $\$ 150$ million public float size to qualify for a shelf offering (Internet Appendix, Table IA1).
} 
4.2 The impact of changes in short-selling regulations

An SEC website and literature search identifies two relevant changes in SEC-imposed short-sale constraints during our research window. We only briefly describe these rules here, but provide a more extensive description in Tables IA2 and IA3 of the Internet Appendix. In October 2007, the SEC made an amendment that strengthened its existing Rule 105. Before the 2007 amendment, SEC Rule 105 prohibited short sellers from covering a short position established in a 'restricted period' consisting of the five trading days before the SEO issue date with shares from the SEO. The Rule 105 amendment prohibits any person setting up a short position within the restricted period from buying shares issued as part of the SEO, regardless of whether they use these shares to cover their short position. This amendment may have made shelf offerings even more attractive, to the extent that shelf issuers did not feel fully protected by existing SEC short-selling constraints for the restricted period of five days before issuance. In contrast, the amendment is unlikely to have completely mitigated the threat of short selling for traditional offerings, as these offerings typically take more than five days to complete. Following this reasoning, we may observe an increase in the use of shelf offerings relative to traditional offerings following the October 2007 Rule 105 amendment. To examine the impact of the amendment, we add a Rule2007 dummy, equal to one for SEOs after the implementation of the amendment and equal to zero otherwise, to our baseline logistic regression. We also add an interaction of this dummy variable with Lendable, to verify whether the impact of firms' SSP on SEO method choice changes following the amendment. Column (2) of Table 3 reports the results. We do not find a significant impact for the variables based on the Rule 2007 amendment. An 
explanation is that shelf issuers already felt sufficiently protected by existing short-selling regulation before the October 2007 Rule 105 amendment, making it irrelevant for the SEO method choice. ${ }^{10}$

A second relevant change in short-sale constraints over our research window results from the SEC's pilot program under Regulation SHO. The pilot program relaxed short-selling restrictions for a randomly-selected subsample comprising one-third of Russell 3000 stocks from May 2, 2005 to July 6, 2007 (SEC 2005). An implication of our main hypothesis is that pilot firms may be more likely to choose shelf over traditional SEOs during the pilot period. This would result in a positive impact of a Pilot firm $\times$ Pilot period interaction on firms' likelihood of choosing a shelf SEO. However, as Table 3, column (3) shows, we do not find a significant impact for the interaction, nor for the individual Pilot firm and Pilot period dummy variables. One reason could be a lack of power in the test. There are only 62 SEOs by 51 pilot firms during the pilot period, of which 55 are shelf offerings and 7 are traditional offerings. Moreover, given that firms were aware of their pilot firm status as early as July 2004 (SEC 2007a), they may have changed their SEO issuance plans well before the start of the pilot period, introducing noise to the measurement of the start of the pilot period. Column (4) of Table 3 combines the regulation dummy variables and interaction terms in columns (2) and (3). We again find no significant impact for any of the dummy variables, with the impact of Lendable remaining significantly

\footnotetext{
${ }^{10}$ In addition to its potential effects on manipulative short selling, the Rule 105 amendment might have made overnight shelf SEOs less attractive (Autore and Gehy 2013). Investors interested in participating in these offerings may not have sufficient time to close out their short positions to qualify for the bona fide purchase exemption of the amendment. In total, $12.52 \%$ of the shelf offerings in our sample are overnight offerings. In an unreported analysis, we do not find a significant reduction in their prevalence following the Rule 105 amendment.
} 
positive. At the end of the Regulation SHO pilot program in July 2007, the SEC relaxed short-selling restrictions for all exchange-listed firms (SEC 2007a). It then re-established a modified uptick rule in February 2010 (Fang 2016). In unreported tests, we find no significant impact for dummy variables capturing these further regulatory changes in our SEO choice model, with the coefficient on Lendable remaining positive and strongly significant.

\subsection{Robustness to alternative short-selling measures}

We verify whether our baseline result is robust to using alternative SSP proxies suggested by the literature. Short-selling activity should be positively related to institutional ownership (IO), since higher IO typically indicates that more shares are available for lending (D'Avolio 2002; Prado 2015). Our second alternative SSP proxy is a dummy variable capturing put options outstanding (Option) at the SEO announcement date. Individual investors who cannot short sell directly in the stock market can take equivalent positions by purchasing put options. Whether a firm has put options outstanding may therefore proxy for investors' desire to short sell the firm's stock (Figlewski and Webb 1993; Danielson and Sorescu 2001; Graham and Hughen 2007). Our third measure captures the value of an issuer's stock actually lent out (OnLoan). Stocks with a higher value for this variable are likely to receive greater short-seller attention, suggesting a higher level of future short selling (Massa et al. 2015). Finally, we consider loan fees, which capture the cost incurred by short sellers. A high loan fee reflects a high cost of borrowing and limits investors' ability to short sell (Saffi and Sigurdsson 2011; Prado et al. 2016). For 
consistency with the other proxies, we measure the short-selling fee variable (InverseFee) as a proxy inversely related to the loan fees of the firm.

Short-selling potential is hard to capture with a single proxy variable, suggesting that an index approach may be suitable (Maskara and Mullineaux 2011). We construct a short-selling determinants index (SSDI) by categorizing seasoned equity issuers each year into quintiles based on Lendable, IO, Option, OnLoan, and InverseFee. We assign a ranking value of one to five to each quintile, with issuers in the quintile with the highest short-selling propensity receiving a value of five and so on down to issuers in the quintile with the lowest propensity receiving a value of one. We assign the components equal weights and compute the index for each issuer in an issuing year by taking the average ranking value based on the five measures.

Table 4 provides summary statistics for the alternative SSP proxies. Panel A provides descriptive statistics for the total sample of SEOs. By construction, our sample is limited to 1,877 offerings with data availability for Lendable. Of these observations, four have missing values for OnLoan and InverseFee due to having no lending activity. IO information is also missing for 18 observations. In total, this leaves 1,855 SEOs for which we have sufficient information to construct SSDI. Panel B provides descriptive statistics for the SSP proxies separately for shelf and traditional SEOs. Consistent with predictions, shelf issuers have higher values for each of the SSP proxies and for SSDI. Panel C reports Pearson correlations between the SSP proxies. The signs of the correlations are consistent with expectations. ${ }^{11}$

\footnotetext{
11 As Cohen et al. (2007) note, a priori we have no clear expectation for the sign of the correlation between the quantity of shares on loan and shorting fees. On the one hand, higher shorting fees (lower InverseFee) might result in lower quantities on loan (lower OnLoan), due to the higher costs of establishing a short position. On the other
} 
Table 5 reports logistic regression estimates using the alternative proxies for anticipated short selling. As predicted, the probability of choosing shelf offerings is positively related to $I O$, Option, and OnLoan. The coefficient on InverseFee is insignificant. A one standard deviation increase in IO (Option, OnLoan) increases the probability of choosing shelf offerings by $1.97 \%$ $(2.98 \%, 3.38 \%)$. Column (5) reports regression results with SSDI as the explanatory variable of interest. The coefficient on SSDI is positive, as predicted. A one standard deviation increase in SSDI from its mean value increases the probability of choosing a shelf offering by $4.12 \%$; at its $25^{\text {th }}$ percentile value, the marginal effect is $6.28 \%$. We conclude that our finding that a higher SSP encourages firms to choose a shelf over a traditional offering is robust to using alternative proxies for potential short selling. We obtain similar results if we restrict these regressions to the 1,855 SEOs for which all SSP proxies are available.

To further verify our baseline result, we conduct an analysis based on actual short sales data rather than ex-ante proxies for short selling. Given the limited power of monthly short interest data (Henry and Koski 2010), we collect daily short-sales data from TAQ Reg SHO (NYSE Short Sales) for the period January 1, 2005 through June 6, 2007 and from NASDAQ for the periods January 1, 2005 through August 31, 2007 and August 3, 2009 through December 31, 2014. We are able to retrieve daily short-sales information for 172 of the traditional offerings and 768 of the shelf offerings in our sample. In line with Henry and Koski (2010), we define abnormal short selling (AbSS) as the difference between short selling relative to trading volume

hand, during high short-selling demand periods, increases in the quantities of shares on loan (higher OnLoan) might go along with increases in shorting fees (lower InverseFee), as equity lending parties are able to extract higher compensation from equity borrowers. The latter scenario seems to dominate in our sample. 
on day $t$ and average daily short selling relative to trading volume during a benchmark period. For robustness, we consider benchmark periods of three different lengths.

Table 6 reports the mean and median values of abnormal short selling, categorized by offer method. In panel A, we use all SEOs with daily short-sales information. Consistent with the premise that shelf offerings protect firms from manipulative short selling, the three abnormal short-sales measures indicate that traditional issuers have significantly higher abnormal short selling between announcement and issue dates than shelf issuers, who do not exhibit abnormal short sales between these dates. In panel B, we only consider SEOs with more than five trading days between their announcement and issue dates (135 shelf SEOs and 170 traditional SEOs). We find no significant differences in mean and median abnormal short sales between shelf and traditional offerings for this subsample, suggesting that the attractiveness of shelf SEOs as a tool to mitigate short selling dissipates for issuers that do not execute the offer within five days of its announcement.

\subsection{Tests addressing alternative explanations}

Shelf offerings allow overvalued firms to access the market quickly to exploit windows of opportunity (Bethel and Krigman 2008). At the same time, stocks of overvalued firms are more likely to be sold short (Dechow et al. 2001). Thus, our results might be driven by firm overvaluation, rather than by a first-order impact of SSP. Reassuringly, our baseline logistic regression results in Table 3 show that the coefficient on Lendable remains positive after controlling for standard firm overvaluation measures. To explore the overvaluation explanation 
further, we re-run our baseline model (Table 3, column 1) using two subsamples of SEOs that are less likely to be motived by overvaluation. The first subsample consists of issuers with Runup and $A d j M T B$ values below their sample medians in the relevant year. In the second subsample, we further exclude SEOs that include secondary shares as part of the offering. Results of these tests again show a strongly significant $(p$-value $<0.01)$, positive impact of Lendable on the choice between shelf and traditional SEOs.

We conduct two further tests to address concerns that the impact of Lendable on firms' SEO method choice arises from omitted variables. First, we analyze the impact of SSP on the speed of issuance within the sample of shelf SEOs. Focusing on shelf issues reduces the risk that unobservable differences between shelf and traditional offerings drive our main finding. We predict that, conditional on a decision to make a shelf offering, firms with a higher SSP exert more effort to complete their offering within five trading days of its announcement, since the SEC imposes strong constraints on short selling during that restricted period. Consistent with this prediction, Table 7, panel A shows that shelf issuers completing their offering within five trading days have higher values of Lendable, our key SSP proxy, than shelf issuers taking longer to complete their offering. Similar results hold when we use our short-selling determinants index (SSDI) as an SSP proxy. Table 7, panel B reports results of a logistic regression with a dependent variable equal to one for shelf issuers completing their offering within five trading days of the announcement date and equal to zero otherwise. As predicted, we find a positive impact of Lendable (column 1) and SSDI (column 2) on firms' propensity to make their shelf offering 
within the short-selling restricted period, even after controlling for other potential firm- and offer-specific differences between these two shelf offering subsamples.

An alternative way to address omitted variable bias is to analyze firms' decision to switch SEO method (Gomes and Phillips 2012). In total, we identify nine instances of firms switching from the shelf to the traditional SEO method over the sample period and 75 instances of the opposite switch. Our key variable of interest in this analysis is the change in Lendable relative to its value at the time of the firm's previous SEO ( $\Delta$ Lendable). We expect $\Delta$ Lendable to be lower for shelf seasoned equity issuers that switch to the traditional method in their subsequent equity offering than for shelf issuers that do not switch offer method in their next equity issue. Consistent with this prediction, we find that the nine shelf-to-traditional switches have a LLendable of 0.019 , compared with 0.074 for 634 shelf-shelf non-switches ( $t$-value for difference in $\Delta$ Lendable between switches and non-switches $=-2.39$ ). Conversely, we expect $\Delta$ Lendable to be higher for traditional seasoned equity issuers that switch to the shelf method in their subsequent equity offering than for traditional issuers that do not switch offer method. Consistent with this prediction, we find that the 75 traditional-to-shelf switches have a $\Delta$ Lendable of 0.017 , compared with -0.025 for 19 traditional-traditional non-switches ( $t$-value for difference in $\Delta$ Lendable between switches and non-switches $=1.94$ ). We obtain similar findings for $\Delta$ Lendable when we analyze the two switching decisions with logistic regressions. In these unreported regressions, we express continuous explanatory variables as changes from their value at the prior SEO, in order to eliminate the effect of unobservable firm and offer characteristics that do not change between successive equity offerings (Gomes and Phillips 2012). 
However, given the small numbers of observations for SEO method switches, the results of these logistic regressions need to be interpreted with caution (King and Zeng 2001).

Overall, we conclude that the significant impact of Lendable on the SEO method choice does not appear to be due to overvaluation or unobservable differences between shelf and traditional SEOs.

\section{Manipulative versus informed short selling}

Our SSP proxy could capture the impact of both manipulative and informed short selling, as both types of short selling can coexist in the so-called 'waiting period' between SEO announcement and issue dates (Henry and Koski 2010).

Unlike manipulative short selling, which has the sole purpose of engineering an artificial discount in the price of new shares (Safieddine and Wilhelm 1996), informed short selling is driven by negative information about a firm. ${ }^{12}$ Like manipulative short sellers, informed short sellers may perceive an upcoming SEO as a cost efficient way to cover their short positions (Henry and Koski 2010). As Autore and Gehy (2013) note, the magnitude of SEO discounts might be so substantial that even somewhat pessimistic investors consider a purchase to be a bargain.

While informed short selling has clear benefits for market efficiency and information dissemination (Christophe et al. 2004; Boehmer et al. 2008, 2010; Diether et al. 2009a,b; Karpoff and Lou 2010; Henry et al. 2015), several previous studies document that managers actively try

\footnotetext{
12 This negative information does not necessarily arise from access to private information (Singal and Xu 2004). Investors might process the same publicly available information (for example, an SEO announcement) in different ways and arrive at different conclusions about its implications for the firm's intrinsic value (Harris and Raviv 1993; Kim and Verrecchia 1994).
} 
to impede informed short selling, for example out of concern for the impact of lower stock prices on their job security and compensation (Liu and Swanson 2011; Lamont 2012; Grullon et al. 2015; Li and Zhang 2015). Applied to SEOs, firms may therefore choose shelf offerings to avoid informed rather than manipulative short selling.

One way to identify which type of short selling dominates is to analyze (counterfactual) offering discounts. The reasoning is as follows. Manipulative short selling reduces the informativeness of the secondary market net order flow, thereby exacerbating the winner's curse and increasing the issue discount (Rock 1986; Kim and Shin 2004; Henry and Koski 2010). To the extent that shelf offerings mitigate the potential for manipulative short selling, we therefore predict higher counterfactual offering discounts for shelf issuers had they chosen a traditional offering instead, under the manipulative short-selling scenario. Informative short selling, in contrast, enhances the informativeness of the secondary market net order flow, as traders can express their beliefs on the value of the stock. It therefore leads to less price uncertainty and lower offering discounts (Henry and Koski 2010). To the extent that shelf offerings mitigate the potential for informed short selling, we therefore predict lower counterfactual offering discounts for shelf issuers had they chosen a traditional offering instead, under the informed short-selling scenario.

To calculate counterfactual offering discounts, we use a generalized two-stage model that controls for a potential selection bias in the SEO method choice (Lee 1978; Fang 2005; Reisel 2014). The first-stage probit regression modeling firms' choice between shelf and traditional 
SEOs includes the same explanatory variables as Table 3 , column (1). ${ }^{13}$ The second stage includes firm and offer characteristics known to influence SEO discounts (Corwin 2001; Altinkilis and Hansen 2003; Mola and Loughran 2004; Henry and Koski 2010; Autore 2011; Huang and Zhang 2011), i.e., LnTA, Volatility, relative offer size (RelOfrSize), a CARPos dummy variable equal to one for firms with a positive cumulative abnormal return over the five days before the issue date, the logarithm of the firm's stock price the day before the issue date (LnPrice), AdjMTB, a dummy variable for NYSE listings, and a Cluster dummy variable for the use of integer pricing. We also include the inverse Mills ratio (Lambda) estimated from the first-stage probit. We then use the coefficients from the second-stage offering discount regression for traditional SEOs (excluding the inverse Mills ratio) to estimate hypothetical discounts for shelf issuers had they selected a traditional offering instead. Table 8, panel A presents the estimation results for the two second-stage offering discount regressions. Overall, these findings are consistent with prior studies. Panel B shows that the mean actual discount for shelf offerings is $4.68 \%$, while the mean hypothetical discount that the same issue would have had using a traditional offer method is $5.28 \%$. The difference between actual and hypothetical discounts is positive $(p<0.001)$, supporting the manipulative short selling scenario.

\section{Conclusion}

This paper examines the impact of firms' short-selling potential (SSP) on their choice of SEO method. Shelf offerings allow qualified firms to offer equity without additional regulatory

\footnotetext{
${ }^{13}$ We do not include additional independent variables from the second-stage regressions in the first-stage probit regression because information such as the offer price is unknown when firms decide to use shelf or traditional offerings.
} 
delays following an initial registration, resulting in a shorter time between their announcement and issue dates. This feature makes it difficult for manipulative short sellers to set up their positions. In contrast, announcement and issue dates for traditional SEOs tend to be several weeks apart. We argue that firms with SSP are therefore more likely to choose shelf over traditional SEOs.

Consistent with this prediction, we find that firms with higher SSP have a higher likelihood of choosing shelf offers. This result is robust to the use of alternative SSP proxies and tests addressing omitted variable bias. An analysis of issue discounts indicates that firms choose shelf offerings to mitigate the threat of manipulative rather than informed short selling.

Overall, we conclude that potential short selling has a first-order effect on the choice between shelf and traditional offerings. Issuers may balance the gains from avoiding manipulative short selling against the costs associated with under-certification, which tend to be higher for shelf offerings (Denis 1991; Bethel and Krigman 2008). This trade-off may explain why some shelf-eligible firms still choose traditional offerings. 


\section{References}

Altinkilis, O., and R.S. Hansen. 2003. Discounting and underpricing in seasoned equity offers. Journal of Financial Economics 69: 285-323.

Asquith, R., and D. Mullins. 1986. Equity issues and offering dilution. Journal of Financial Economics 15: 61-89.

Autore, D.M. 2011. Does Rule 10b-21 increase SEO discounting? Journal of Financial Intermediation 20: 231-247.

Autore, D.M., and D. Gehy. 2013. Changing the rules again: Short selling in connection with public equity offers. Journal of Banking and Finance 37: 1974-1985.

Autore, D.M., R. Kumar, and D.K. Shome. 2008. The revival of shelf-registered corporate equity offerings. Journal of Corporate Finance 14: 32-50.

Bethel, J.E., and L. Krigman. 2008. Managing the costs of issuing common equity: The role of registration choice. Quarterly Journal of Finance and Accounting 47: 57-85.

Boehmer, E., Z.R. Huszar, and B.D. Jordan. 2010. The good news in short interest. Journal of Financial Economics 96: 80-97.

Boehmer, E., C.M. Jones, and X. Zhang. 2008. Which shorts are informed? Journal of Finance 63: 491-527.

Bortolotti, B., W. Megginson, and S. Smart. 2008. The rise of accelerated seasoned equity underwritings. Journal of Applied Corporate Finance 20: 35-57.

Christophe, S.E., M.G. Ferri, and J.J. Angel. 2004. Short-selling prior to earnings announcements. Journal of Finance 59: 1845-1875.

Cohen, L., K. Diether, and C. Malloy. 2007. Supply and demand shifts in the shorting market. Journal of Finance 62: 2061-2096.

Corwin, S.A. 2003. The determinants of underpricing for seasoned equity offers. Journal of Finance 58: 2249-2279.

Danielson, B.R., and S.M. Sorescu. 2001. Why do option introductions depress stock prices? A study of diminishing short-sale constraints. Journal of Financial and Quantitative Analysis 36: $451-484$.

D’Avolio, G. 2002. The market for borrowing stock. Journal of Financial Economics 66: 271306.

Dechow, P., A. Hutton, L. Meulbroek, and R. Sloan. 2001. Short-sellers, fundamental analysis and stock returns. Journal of Financial Economics 61: 77-106.

De Jong, A., M. Dutordoir, and P. Verwijmeren. 2011. Why do convertible issuers simultaneously repurchase stock? An arbitrage-based explanation. Journal of Financial Economics 100: $113-129$.

Denis, D.J. 1991. Shelf registration and the market for seasoned equity offerings. Journal of Business 64: 189-212.

Deshmukh, S., K.J. Gamble, and K.M. Howe. 2017. Informed short selling around SEO announcements. Journal of Corporate Finance 46: 121-138. 
Diether, K.B., K.H. Lee, and I.M. Werner. 2009a. It is SHO time! Short-sale price tests and market quality. Journal of Finance 64: 37-73.

Diether, K.B., K.H. Lee, and I.M. Werner. 2009b. Short sale strategies and return predictability. Review of Financial Studies 22: 575-607.

Duca, E., M. Dutordoir, C. Veld, and P. Verwijmeren. 2012. Why are convertible bond announcements associated with increasingly negative issuer stock returns? An arbitrage-based explanation. Journal of Banking and Finance 36: 2884-2899.

Duffie, D., N. Garleanu, and L.H. Pedersen. 2002. Securities lending, shorting, and pricing. Journal of Finance 66: 307-339.

Fama, E.F., and K.R. French. 1997. Industry costs of equity. Journal of Financial Economics 43: 153-193.

Fang, L.H. 2005. Investment bank reputation and the price and quality of underwriting services. Journal of Finance 60: 2729-2761.

Fang, V.W., A.H. Huang, and J.M. Karpoff. 2016. Short selling and earnings management: A controlled experiment. Journal of Finance 71: 1251-1294.

Federal Register, October 29, 1992. Available at

https://www.gpo.gov/fdsys/pkg/FR-1992-10-29/pdf/FR-1992-10-29.pdf\#page=42. Last accessed on September 16, 2017.

Figlewski, S., and G.P. Webb. 1993. Options, short sales, and market completeness. Journal of Finance 48: 761-777.

Galai, D. and R.W. Masulis. 1976. The option pricing model and the risk factor of stock. Journal of Financial Economics 3: 53-81.

Gao, X., and J.R. Ritter. 2010. The marketing of seasoned equity offerings. Journal of Financial Economics 97: 33-52.

Gerard, B., and V. Nanda. 1993. Trading and manipulation around seasoned equity offerings. Journal of Finance 48: 213-245.

Gomes, A. and G. Phillips. 2012. Why do public firms issue private and public securities? Journal of Financial Intermediation 21: 619-658.

Graham, J.E., and J.C. Hughen. 2007. Ownership structure, expectations, and short sales on the Nasdaq. Journal of Economics and Finance 31: 33-48.

Grullon, G., S. Michenaud, and J.P. Weston. 2015. The real effects of short-selling constraints. Review of Financial Studies 28: 1737-1767.

Gustafson, M.T. 2017. Price pressure and overnight seasoned equity offerings. Available at SSRN: https://papers.ssrn.com/sol3/papers.cfm?abstract_id=1945014.

Gustafson, M.T. and P. Iliev. 2017. The effects of removing barriers to equity issuance. Journal of Financial Economics 124: 580-598.

Harris, M., and A. Raviv. 1993. Differences of opinion make a horse race. Review of Financial Studies 6: 473-506.

Henry, T.R., D.J. Kisgen, and J. Wu. 2015. Equity short selling and bond rating downgrades. Journal of Financial Intermediation 24: 89-111. 
Henry, T.R., and J.L. Koski. 2010. Short selling around seasoned equity offerings. Review of Financial Studies 23: 4389-4418.

Huang, R., and D. Zhang. 2011. Managing underwriters and the marketing of seasoned equity offerings. Journal of Financial and Quantitative Analysis 46: 141-170.

Karpoff, J.M., and X. Lou. 2010. Short sellers and financial misconduct. Journal of Finance 65: 1879-1913.

Kim, K., and H. Shin. 2004. The puzzling increase in the underpricing of seasoned equity offerings. Financial Review 39: 343-65.

Kim, K., and R.E. Verrecchia. 1994. Market liquidity and volume around earnings announcements. Journal of Accounting and Economics 17: 41-67.

King, G., and L. Zeng. 2001. Logistic regression in rare events data. Political Analysis 9: 137163.

Krasker, W.S., 1986. Stock price movements in response to stock issues under asymmetric information. Journal of Finance 41: 93-105.

Lamont, O.A. 2012. Go down fighting: short sellers vs. firms. Review of Asset Pricing Studies 2: $1-30$.

Lease, R.C., R.W. Masulis, and J.R. Page. 1991. An investigation of market microstructure impacts on event study returns. Journal of Finance 46: 1523-1536.

Lee, L.F. 1978. Unionism and wage rates: A simultaneous equations model with qualitative and limited dependent variables. International Economic Review 19: 415-433.

Li, Y., and L. Zhang. 2015. Short selling pressure, stock price behavior, and management forecast precision: Evidence from a natural experiment. Journal of Accounting Research 53: $79-117$.

Liu, H., and E.P. Swanson. 2011. Do corporate managers trade against short sellers? Available at SSRN: https://ssrn.com/abstract $=1899354$.

Maskara, P.K., and D.J. Mullineaux. 2011. Information asymmetry and self-selection bias in bank loan announcement studies. Journal of Financial Economics 101: 684-694.

Massa, M., B. Zhang, and H. Zhang. 2015. The invisible hand of short selling: Does short selling discipline earnings management? Review of Financial Studies 28: 1701-1736.

Masulis, R.W., and A.N. Korwar. 1986. Seasoned equity offerings: An empirical investigation. Journal of Financial Economics 15: 91-118.

Mitchell, M., T. Pulvino, and E. Stafford. 2004. Price pressure around mergers. Journal of Finance 59: 31-63.

Mola, S., and T. Loughran. 2004. Discounting and clustering in seasoned equity offering prices. Journal of Financial and Quantitative Analysis 39: 1-23.

Prado, M.P. 2015. Future lending income and security value. Journal of Financial and Quantitative Analysis 50: 869-902.

Prado, M.P., P.A.C. Saffi, and J. Sturgess. 2016. Ownership structure, limits to arbitrage, and stock returns: Evidence from equity lending markets. Review of Financial Studies 29: 32113244. 
Reisel, N. 2014. On the value of restrictive covenants: Empirical investigation of public bond issues. Journal of Corporate Finance 27: 251-268.

Rock, K. 1986. Why new issues are underpriced. Journal of Financial Economics 15: 187-212.

Saffi, P.A.C., and K. Sigurdsson. 2011. Price efficiency and short selling. Review of Financial Studies 24: 821-852.

Safieddine, A., and W.J. Wilhelm. 1996. An empirical investigation of short-selling activity prior to seasoned equity offerings. Journal of Finance 51: 729-749.

SDC. 2016. New Issues Definitions, available at http://mergers.thomsonib.com/td/DealSearch/help/nidef.htm. Last accessed on September 16, 2017.

SEC. 2005. Regulation SHO - Pilot program. Available at https://www.sec.gov/spotlight/shopilot.htm. Last accessed on September 16, 2017.

SEC. 2007a. Economic analysis of the short sale price restrictions under the Regulation SHO Pilot: A study by the staff of the Office of Economic Analysis. Available at https://www.sec.gov/news/studies/2007/regshopilot020607.pdf. Last accessed on September 16, 2017.

SEC. 2007b. Revisions to the eligibility requirements for primary securities offerings on forms S-3 and F-3. Available at https://www.sec.gov/rules/final/2007/33-8878.pdf. Last accessed on September 16, 2017.

SEC. 2017a. Form S-3 registration statement under the Securities Act of 1933. Available at https://www.sec.gov/files/forms-3.pdf. Last accessed on September 16, 2017.

SEC. 2017b. Eligibility of smaller companies to use Form S-3 or F-3 for primary securities offerings. Available at https://www.sec.gov/info/smallbus/secg/s3f3-secg.htm. Last accessed on September 16, 2017.

Singal, V., and L. Xu. 2005. Do short sellers know more? Evidence from a natural experiment. Available at SSRN: https://papers.ssrn.com/sol3/papers.cfm?abstract_id=687795. 


\section{Figure 1}

Distribution of the number of trading days between announcement and issue dates for shelf and traditional offerings

This bar chart shows the proportions of sample shelf and traditional offerings with the indicated number of trading days between SEO announcement and issue dates. The black bars represent shelf offerings, and the white bars represent traditional offerings. The sample includes 1,877 SEOs from September 2004 to December 2014, comprising 1,597 shelf and 280 traditional offerings.

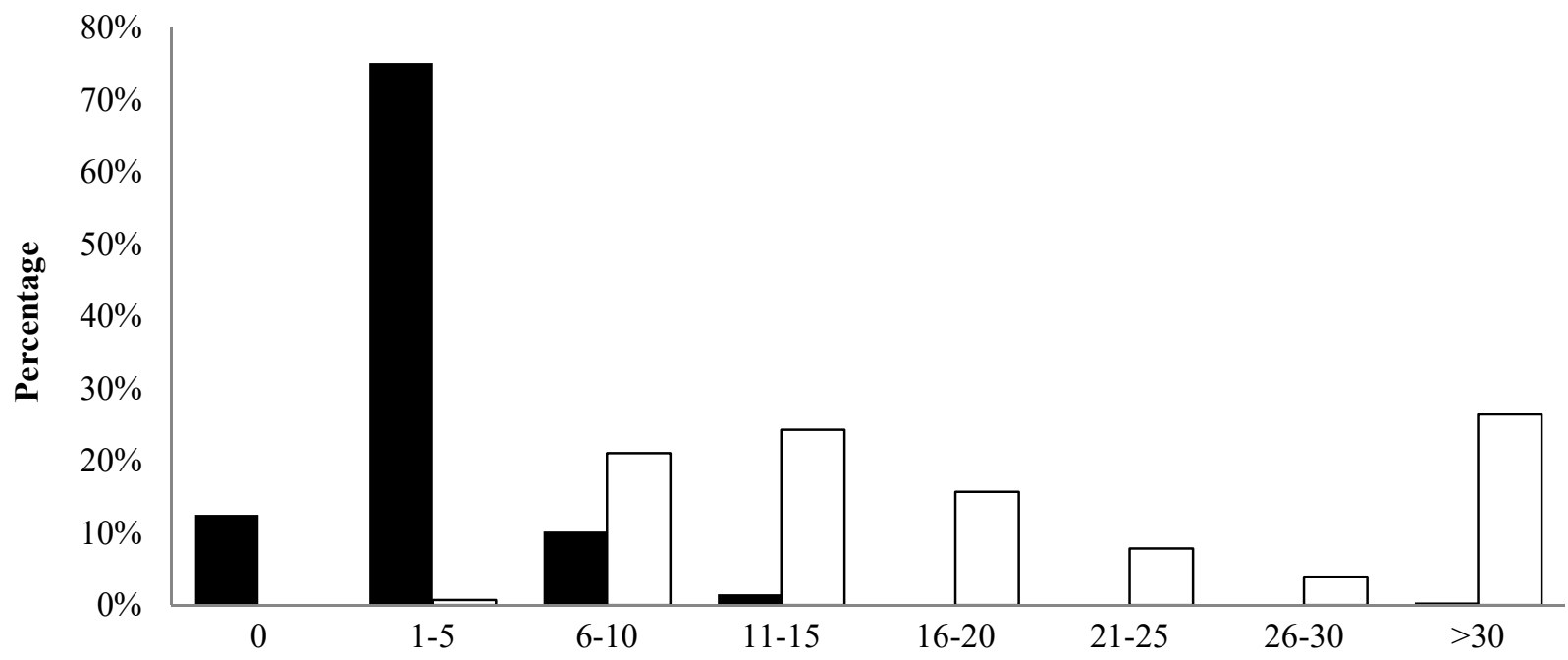

Number of days between announcement and issuance

- Shelf offerings $\square$ Traditional offerings 


\section{Figure 2}

\section{Timeline for shelf and traditional offerings}

This figure shows the registration and issuance timelines for shelf and traditional SEOs. The filing date is the date on which a firm first files its registration of the offering with the SEC. For shelf issues, the launch date is the date on which a firm first files the deal itself (i.e., the shelf takedown) with the SEC. The issue date is the date on which the shares are sold. We retrieve the filing, launch, and issue dates from the SDC. The reported numbers are calculated using our sample of 1,877 SEOs from 2004 to 2014.

\section{Shelf offerings}

Filing date

Launch date $=$ Announcement date

Issue date

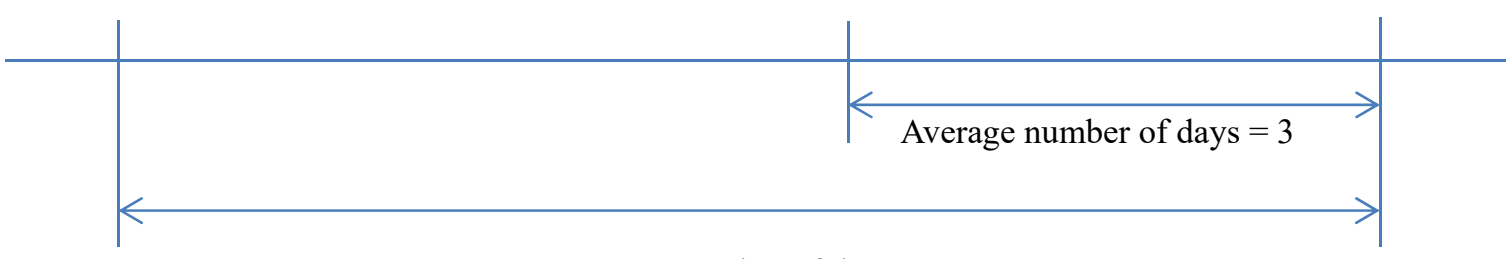

Average number of days $=203$

\section{Traditional offerings}

Filing date $=$ Announcement date

Issue date

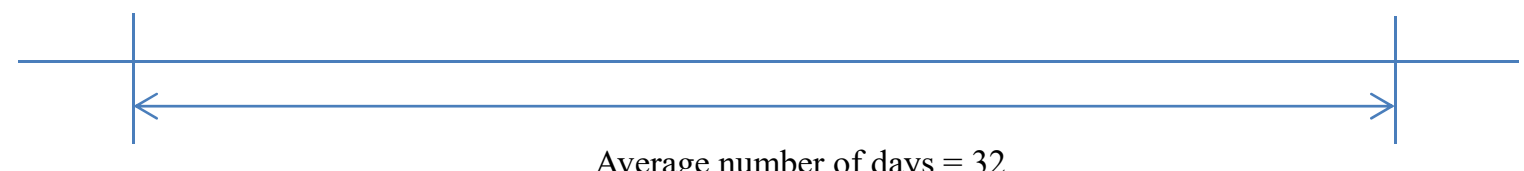

Average number of days $=32$ 


\section{Table 1: Distribution of SEOs by year}

This table gives the number and proceeds (in millions of U.S. dollars) by year for our total sample of seasoned equity offerings (SEOs), as well as for shelf and traditional SEOs. We also report the numbers and proceeds of shelf and traditional offerings relative to the total sample offerings. The sample includes 1,877 SEOs from September 2004 to December 2014 obtained from the SDC, comprising 1,597 shelf and 280 traditional offerings. An issuer must be a U.S.-based company listed on the New York Stock Exchange (NYSE), NYSE MKT or NASDAQ. We exclude IPOs, rights offerings, unit issues, closed-end funds, REITs, simultaneous international offerings, offerings by non-U.S. firms and pure secondary offerings. An issuer must be qualified to file a shelf registration and have relevant stock price, company accounts, and equity lending data available on CRSP, Compustat, and Markit, respectively.

\begin{tabular}{|c|c|c|c|c|c|c|c|c|c|c|}
\hline \multirow[t]{2}{*}{ Year } & \multicolumn{2}{|c|}{ Total SEOs } & \multicolumn{4}{|c|}{ Shelf SEOs } & \multicolumn{4}{|c|}{ Traditional SEOs } \\
\hline & $\begin{array}{c}\text { Number } \\
\text { (1) }\end{array}$ & $\begin{array}{c}\text { Proceeds } \\
\text { (2) }\end{array}$ & Number & $\%$ of $(1)$ & Proceeds & $\%$ of $(2)$ & Number & $\%$ of $(1)$ & Proceeds & $\%$ of $(2)$ \\
\hline 2004 & 59 & $8,543.4$ & 48 & $81.4 \%$ & $7,062.8$ & $82.7 \%$ & 11 & $18.6 \%$ & $1,480.6$ & $17.3 \%$ \\
\hline 2005 & 150 & $18,123.9$ & 109 & $72.7 \%$ & $14,820.0$ & $81.8 \%$ & 41 & $27.3 \%$ & $3,303.9$ & $18.2 \%$ \\
\hline 2006 & 159 & $23,142.4$ & 108 & $67.9 \%$ & $17,027.3$ & $73.6 \%$ & 51 & $32.1 \%$ & $6,115.1$ & $26.4 \%$ \\
\hline 2007 & 153 & $26,707.8$ & 118 & $77.1 \%$ & $21,248.2$ & $79.6 \%$ & 35 & $22.9 \%$ & $5,459.6$ & $20.4 \%$ \\
\hline 2008 & 129 & $97,882.0$ & 112 & $86.8 \%$ & $96,049.3$ & $98.1 \%$ & 17 & $13.2 \%$ & $1,832.7$ & $1.9 \%$ \\
\hline 2009 & 297 & $106,531.4$ & 277 & $93.3 \%$ & $102,539.7$ & $96.3 \%$ & 20 & $6.7 \%$ & $3,991.7$ & $3.7 \%$ \\
\hline 2010 & 205 & $41,340.2$ & 190 & $92.7 \%$ & $39,468.7$ & $95.5 \%$ & 15 & $7.3 \%$ & $1,871.5$ & $4.5 \%$ \\
\hline 2011 & 131 & $40,755.0$ & 116 & $88.5 \%$ & $39,058.8$ & $95.8 \%$ & 15 & $11.5 \%$ & $1,696.2$ & $4.2 \%$ \\
\hline 2012 & 166 & $22,554.8$ & 155 & $93.4 \%$ & $20,960.5$ & $92.9 \%$ & 11 & $6.6 \%$ & $1,594.3$ & $7.1 \%$ \\
\hline 2013 & 214 & $35,662.5$ & 191 & $89.3 \%$ & $32,672.1$ & $91.6 \%$ & 23 & $10.7 \%$ & $2,990.4$ & $8.4 \%$ \\
\hline 2014 & 214 & $35,923.6$ & 173 & $80.8 \%$ & $29,459.4$ & $82.0 \%$ & 41 & $19.2 \%$ & $6,464.2$ & $18.0 \%$ \\
\hline Total & 1,877 & $457,167.0$ & 1,597 & $85.1 \%$ & $420,366.8$ & $92.0 \%$ & 280 & $14.9 \%$ & $36,800.2$ & $8.0 \%$ \\
\hline
\end{tabular}




\section{Table 2: Firm and offer characteristics}

Panel A reports mean and median values of firm and offer characteristics. A + (-) sign next to a variable name indicates that we expect it to be higher (lower) for shelf than traditional SEOs (with $+/-$ indicating that we have no clear expectation). Panel B reports Pearson correlations between Lendable and control variables, with the numbers referring to the corresponding variable numbers in panel A. The sample includes 1,877 SEOs from September 2004 to December 2014 from the SDC, comprising 1,597 shelf and 280 traditional offerings. The Appendix defines the variables. $p$-values for differences in means (medians) between shelf and traditional SEOs are based on standard $t$-tests (Wilcoxon signed-rank tests). ${ }^{*},{ }^{* *},{ }^{* * *}$ indicate significance at $10 \%, 5 \%$, and $1 \%$.

\begin{tabular}{|c|c|c|c|c|c|c|c|c|c|c|c|c|c|c|c|}
\hline \multicolumn{16}{|c|}{ Panel A: Descriptive statistics } \\
\hline \multirow{3}{*}{\multicolumn{4}{|c|}{ Variable (sign) }} & \multicolumn{8}{|c|}{ SEO method } & \multicolumn{4}{|c|}{ Difference } \\
\hline & & & & \multicolumn{4}{|c|}{ Shelf } & \multicolumn{4}{|c|}{ Traditional } & \multirow{2}{*}{\multicolumn{2}{|c|}{$\begin{array}{c}\text { Mean } \\
p \text {-value }\end{array}$}} & \multirow{2}{*}{\multicolumn{2}{|c|}{$\begin{array}{l}\text { Median } \\
p \text {-value }\end{array}$}} \\
\hline & & & & & Mean & & Median & & Mean & & Median & & & & \\
\hline \multicolumn{4}{|c|}{ (1) Lendable (+) } & & 0.163 & & 0.156 & & 0.079 & & 0.054 & & 0.000 & & 0.000 \\
\hline \multicolumn{4}{|c|}{ (2) $B A S(\%)(-)$} & & 0.047 & & 0.042 & & 0.051 & & 0.048 & & 0.015 & & 0.000 \\
\hline \multicolumn{4}{|c|}{ (3) Dispersion (-) } & & 0.119 & & 0.038 & & 0.289 & & 0.056 & & 0.000 & & 0.002 \\
\hline \multicolumn{4}{|c|}{ (4) DispersionDum (+/-) } & & 0.116 & & 0.000 & & 0.307 & & 0.000 & & 0.000 & & 0.000 \\
\hline \multicolumn{4}{|c|}{ (5) Analyst (+/-) } & & 8.793 & & 8.000 & & 5.846 & & 5.000 & & 0.000 & & 0.000 \\
\hline \multicolumn{4}{|c|}{ (6) Volatility (+) } & & 0.563 & & 0.484 & & 0.561 & & 0.524 & & 0.937 & & 0.071 \\
\hline \multicolumn{4}{|c|}{ (7) Runup (+/-) } & & 0.448 & & 0.149 & & 0.425 & & 0.335 & & 0.799 & & 0.000 \\
\hline \multicolumn{4}{|c|}{ (8) $\operatorname{AdjMTB}(+/-)$} & & -43.757 & & -26.252 & & -35.310 & & -16.989 & & 0.011 & & 0.016 \\
\hline \multicolumn{4}{|c|}{ (9) $\operatorname{LnTA}(+/-)$} & & 6.595 & & 6.358 & & 5.504 & & 5.060 & & 0.000 & & 0.000 \\
\hline \multicolumn{4}{|c|}{ (10) Turnover $(\%)(+/-)$} & & 1.266 & & 0.908 & & 0.998 & & 0.673 & & 0.001 & & 0.000 \\
\hline \multicolumn{4}{|c|}{ (11) Leverage $(+/-)$} & & 0.225 & & 0.163 & & 0.160 & & 0.075 & & 0.000 & & 0.000 \\
\hline \multicolumn{4}{|c|}{ (12) $F C F(+/-)$} & & -0.158 & & -0.011 & & -0.112 & & -0.004 & & 0.075 & & 0.086 \\
\hline \multicolumn{4}{|c|}{ (13) NYSE (dummy) $(+/-)$} & & 0.352 & & 0.000 & & 0.207 & & 0.000 & & 0.000 & & 0.000 \\
\hline \multicolumn{4}{|c|}{ (14) RelOfrSize (+/-) } & & 0.383 & & 0.139 & & 0.947 & & 0.548 & & 0.000 & & 0.000 \\
\hline \multicolumn{4}{|c|}{ (15) Sequence (dummy) (+) } & & 0.487 & & 0.000 & & 0.118 & & 0.000 & & 0.000 & & 0.000 \\
\hline \multicolumn{4}{|c|}{ (16) Secondary (dummy) (-) } & & 0.089 & & 0.000 & & 0.536 & & 1.000 & & 0.000 & & 0.000 \\
\hline \multicolumn{16}{|c|}{ Panel B: Pearson correlations between Lendable and control variables } \\
\hline \multirow[b]{2}{*}{$(1)$} & $(2)$ & $(3)$ & $(4)$ & $(5)$ & $(6)$ & $(7)$ & $(8)$ & $(9)$ & (10) & $(11)$ & (12) & $(13)$ & (14) & $(15)$ & (16) \\
\hline & $0.075^{* * *}$ & -0.002 & $-0.311 * * *$ & $0.454 * * *$ & $0.102 * * *$ & -0.036 & 0.020 & $0.438 * * *$ & $0.276^{* * *}$ & $0.107^{* * *}$ & $0.145^{* * *}$ & $0.232 * * *$ & $-0.240 * * *$ & $0.247^{* * *}$ & $* \quad-0.228 * * *$ \\
\hline
\end{tabular}




\section{Table 3: The impact of short-selling potential (SSP) on the choice of SEO offer method}

This table presents the results of logistic regressions examining the impact of seasoned equity issuers' short-selling potential (SSP), proxied by Lendable, on their SEO method choice, controlling for firm and offer characteristics. Columns (2) to (4) also control for short-selling regulations over the sample period. A sign of + (-) next to a variable name indicates that we expect it to have a positive (negative) impact on the likelihood of choosing a shelf over a traditional SEO (with $+/-$ indicating that we have no clear expectation). The dependent variable equals one for shelf and zero for traditional offerings. All regressions include year and industry fixed effects. Industry effects are based on the Fama-French 12-industry classification (Fama and French 1997). The Appendix defines the explanatory variables. $t$-statistics are in parentheses. Pseudo $R$-sqr is the likelihood-based pseudo $R$-square. $N$ is the number of observations. ${ }^{*},{ }^{* *},{ }^{* * *}$ indicate significance at $10 \%, 5 \%$, and $1 \%$.

\begin{tabular}{|c|c|c|c|c|}
\hline & (1) & (2) & (3) & (4) \\
\hline \multirow[t]{2}{*}{ Lendable $(+)$} & $7.440 * * *$ & $7.153 * * *$ & $7.589 * * *$ & $7.156^{* * *}$ \\
\hline & $(5.48)$ & $(3.09)$ & $(5.56)$ & $(3.08)$ \\
\hline \multirow[t]{2}{*}{ Rule2007 (-) } & & -0.417 & & -0.390 \\
\hline & & $(-0.60)$ & & $(-0.52)$ \\
\hline \multirow[t]{2}{*}{ Lendable $\times$ Rule2007 (+) } & & 0.415 & & 0.629 \\
\hline & & $(0.16)$ & & $(0.24)$ \\
\hline \multirow[t]{2}{*}{ Pilot period (+/-) } & & & 0.144 & 0.069 \\
\hline & & & $(0.39)$ & $(0.17)$ \\
\hline \multirow[t]{2}{*}{ Pilot firm $(+/-)$} & & & -0.424 & -0.436 \\
\hline & & & $(-1.16)$ & $(-1.18)$ \\
\hline \multirow[t]{2}{*}{ Pilot firm $\times$ Pilot period $(+)$} & & & 0.428 & 0.459 \\
\hline & & & $(0.72)$ & $(0.76)$ \\
\hline \multirow[t]{2}{*}{ BAS (-) } & $-71.029 * * *$ & $-70.763 * * *$ & $-70.815^{* * *}$ & $-70.544 * * *$ \\
\hline & $(-5.40)$ & $(-5.38)$ & $(-5.39)$ & $(-5.37)$ \\
\hline \multirow[t]{2}{*}{ Dispersion (-) } & $-0.426 * * *$ & $-0.426 * * *$ & $-0.425 * * *$ & $-0.426 * * *$ \\
\hline & $(-2.95)$ & $(-2.95)$ & $(-2.98)$ & $(-2.98)$ \\
\hline \multirow[t]{2}{*}{ DispersionDum (+/-) } & -0.193 & -0.186 & -0.196 & -0.191 \\
\hline & $(-0.86)$ & $(-0.83)$ & $(-0.89)$ & $(-0.85)$ \\
\hline \multirow[t]{2}{*}{ Analyst (+/-) } & 0.032 & 0.032 & 0.032 & 0.032 \\
\hline & $(1.17)$ & $(1.17)$ & $(1.16)$ & $(1.16)$ \\
\hline \multirow[t]{2}{*}{ Volatility (+) } & $3.695 * * *$ & $3.684 * * *$ & $3.650 * * *$ & $3.639 * * *$ \\
\hline & $(3.48)$ & $(3.47)$ & $(3.44)$ & $(3.43)$ \\
\hline \multirow[t]{2}{*}{ Runup (+/-) } & $0.185^{*}$ & $0.184^{*}$ & $0.196^{*}$ & $0.195 *$ \\
\hline & $(1.80)$ & $(1.80)$ & $(1.90)$ & $(1.90)$ \\
\hline \multirow[t]{2}{*}{$\operatorname{AdjMTB}(+/-)$} & -0.000 & -0.000 & -0.000 & -0.000 \\
\hline & $(-0.06)$ & $(-0.10)$ & $(-0.11)$ & $(-0.15)$ \\
\hline \multirow[t]{2}{*}{$\operatorname{LnTA}(+/-)$} & -0.080 & -0.081 & -0.076 & -0.079 \\
\hline & $(-1.04)$ & $(-1.05)$ & $(-0.99)$ & $(-1.01)$ \\
\hline
\end{tabular}


Table 3: Continued

\begin{tabular}{lcccc}
\hline & $(1)$ & $(2)$ & $(3)$ & $(4)$ \\
\cline { 2 - 5 } Turnover $(+/-)$ & -0.142 & -0.143 & -0.136 & -0.138 \\
& $(-1.52)$ & $(-1.53)$ & $(-1.46)$ & $(-1.48)$ \\
Leverage $(+/-)$ & $0.667^{*}$ & $0.656^{*}$ & 0.641 & 0.638 \\
& $(1.68)$ & $(1.65)$ & $(1.61)$ & $(1.60)$ \\
FCF $(+/-)$ & $-1.014^{* * *}$ & $-1.003^{* * *}$ & $-1.027^{* * *}$ & $-1.017^{* * *}$ \\
& $(-3.01)$ & $(-2.98)$ & $(-3.03)$ & $(-3.00)$ \\
NYSE $(+/-)$ & $0.405^{*}$ & $0.408^{*}$ & $0.422^{*}$ & $0.422^{*}$ \\
& $(1.70)$ & $(1.71)$ & $(1.77)$ & $(1.77)$ \\
RelOfrSize $(+/-)$ & $-0.301^{* * *}$ & $-0.300^{* * *}$ & $-0.303^{* * *}$ & $-0.302^{* * *}$ \\
& $(-3.29)$ & $(-3.27)$ & $(-3.30)$ & $(-3.28)$ \\
Sequence $(+)$ & $0.837^{* * *}$ & $0.847^{* * *}$ & $0.859^{* * *}$ & $0.867^{* * *}$ \\
Secondary $(-)$ & $(3.66)$ & $(3.69)$ & $(3.74)$ & $(3.76)$ \\
& $-1.873^{* * *}$ & $-1.876^{* * *}$ & $-1.885^{* * *}$ & $-1.887^{* * *}$ \\
Pseudo $R$-sqr & $(-9.03)$ & $(-9.04)$ & $(-9.01)$ & $(-9.01)$ \\
$N$ & 0.361 & 0.361 & 0.362 & 0.362 \\
& 1,877 & 1,877 & 1,877 & 1,877 \\
\hline
\end{tabular}


Table 4: Summary statistics of short-selling potential proxies

This table reports summary statistics of short-selling potential (SSP) proxies for our sample (Panel A), a comparison of shelf offerings with traditional offerings for each SSP proxy (Panel B), and pairwise correlation coefficients between the individual SSP proxies (Panel C). The Appendix defines the variables. $N$ is the number of observations. $p$-values for differences in means (medians) between shelf and traditional offerings are based on standard $t$-tests (Wilcoxon signed-rank tests). ${ }^{*},{ }^{* *},{ }^{* * *}$ indicate significance at $10 \%, 5 \%$, and $1 \%$.

\begin{tabular}{lcccc} 
Panel A: Summary statistics of SSP proxies & & & \\
& $N$ & Mean & Median & Standard deviation \\
\cline { 2 - 4 } Lendable & 1,877 & 0.151 & 0.139 & 0.105 \\
IO & 1,859 & 0.585 & 0.596 & 0.266 \\
Option & 1,877 & 0.685 & 1.000 & 0.465 \\
OnLoan & 1,873 & 0.053 & 0.032 & 0.059 \\
InverseFee & 1,873 & 2.989 & 3.000 & 1.414 \\
SSDI & 1,855 & 3.144 & 3.200 & 1.043
\end{tabular}

Panel B: Comparison of shelf offerings with traditional offerings

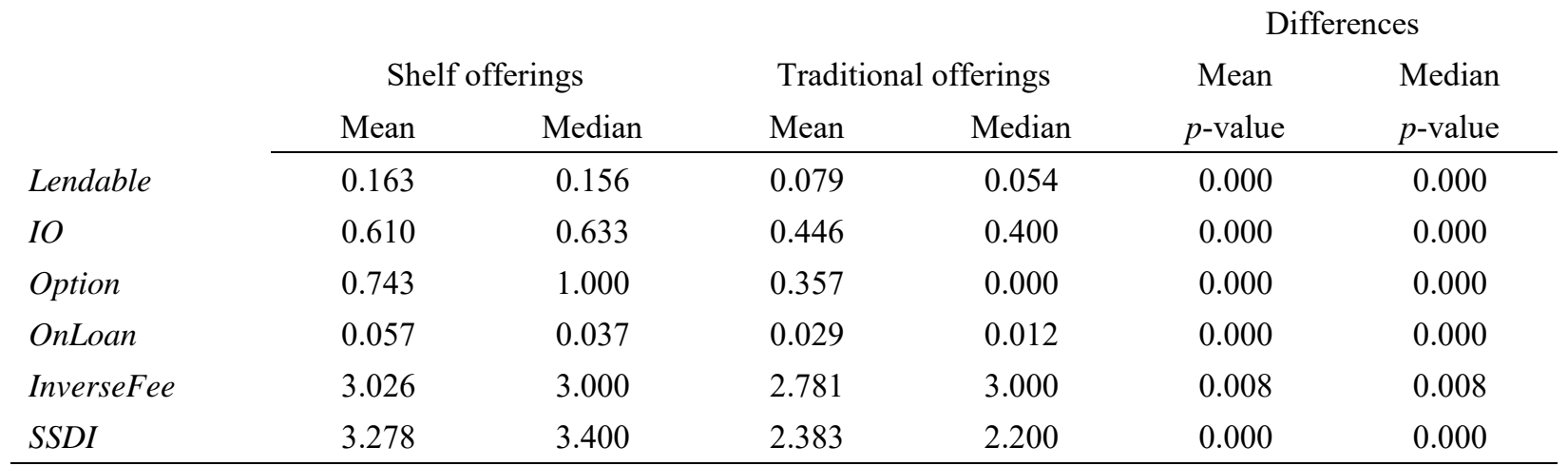

Panel C: Pearson correlation matrix of SSP proxies

\begin{tabular}{llllll} 
& SSDI & Lendable & IO & Option & OnLoan \\
\cline { 2 - 6 } Lendable & $0.744^{* * *}$ & 1 & & & \\
IO & $0.809^{* * *}$ & $0.650^{* * *}$ & 1 & & \\
Option & $0.714^{* * *}$ & $0.394^{* * *}$ & $0.404^{* * *}$ & 1 & \\
OnLoan & $0.449^{* * *}$ & $0.477^{* * *}$ & $0.369^{* * *}$ & $0.301 * * *$ & 1 \\
InverseFee & $0.523^{* * *}$ & $0.418^{* * *}$ & $0.421^{* * *}$ & $0.168^{* * *}$ & $-0.213^{* * *}$ \\
\hline
\end{tabular}


Table 5: Analysis of alternative short-selling potential proxies

This table presents the results of logistic regressions using different individual short-selling potential (SSP) proxies, as well as a short-selling determinants index (SSDI) measured as the average quintile ranking of an offering based on all SSP proxies (Lendable, IO, Option, OnLoan, and InverseFee) A sign of $+(-)$ next to a variable name indicates that we expect it to have a positive (negative) impact on the likelihood of choosing a shelf over a traditional SEO (with +/- indicating that we have no clear expectation). The dependent variable equals one for shelf and zero for traditional offerings. All regressions include year and industry fixed effects. Industry effects are based on the Fama-French 12-industry classification (Fama and French 1997). The Appendix defines the explanatory variables. $t$-statistics are in parentheses. Pseudo $R$-sqr is the likelihood-based pseudo $R$-square. $N$ is the number of observations. ${ }^{* * *},{ }^{* * *}$ indicate significance at $10 \%, 5 \%$, and $1 \%$.

\begin{tabular}{lccccc}
\hline SSP $=$ & IO & Option & OnLoan & InverseFee & SSDI \\
& $(1)$ & $(2)$ & $(3)$ & $(4)$ & $(5)$ \\
\cline { 2 - 5 } SSP (+) & $1.173^{* * *}$ & $1.049^{* * *}$ & $9.431^{* * *}$ & -0.085 & $0.673^{* * *}$ \\
& $(2.94)$ & $(5.47)$ & $(3.86)$ & $(-1.26)$ & $(6.01)$ \\
BAS (-) & $-72.129 * * *$ & $-75.384^{* * *}$ & $-73.617^{* * *}$ & $-73.812^{* * *}$ & $-73.808^{* * *}$ \\
& $(-5.42)$ & $(-5.57)$ & $(-5.54)$ & $(-5.56)$ & $(-5.46)$ \\
Dispersion (-) & $-0.443^{* * *}$ & $-0.407^{* * *}$ & $-0.452^{* * *}$ & $-0.438^{* * *}$ & $-0.424^{* * *}$ \\
& $(-3.17)$ & $(-2.84)$ & $(-3.27)$ & $(-3.14)$ & $(-2.92)$ \\
DispersionDum (+/-) & -0.269 & $-0.365^{*}$ & -0.298 & $-0.416^{*}$ & -0.185 \\
& $(-1.20)$ & $(-1.65)$ & $(-1.33)$ & $(-1.87)$ & $(-0.82)$ \\
Analyst (+/-) & $0.048^{*}$ & 0.035 & $0.048^{*}$ & $0.066^{* *}$ & 0.024 \\
& $(1.76)$ & $(1.32)$ & $(1.77)$ & $(2.43)$ & $(0.87)$ \\
Volatility (+) & $3.701^{* * *}$ & $3.839^{* * *}$ & $3.722^{* * *}$ & $3.699^{* * *}$ & $3.854^{* * *}$ \\
& $(3.46)$ & $(3.50)$ & $(3.49)$ & $(3.46)$ & $(3.54)$ \\
Runup (+/-) & $0.202^{*}$ & 0.158 & $0.244^{* *}$ & $0.193 *$ & $0.221^{* *}$ \\
& $(1.90)$ & $(1.51)$ & $(2.30)$ & $(1.78)$ & $(2.07)$ \\
AdjMTB (+/-) & -0.000 & -0.001 & -0.001 & -0.001 & -0.000 \\
& $(-0.15)$ & $(-0.27)$ & $(-0.51)$ & $(-0.39)$ & $(-0.17)$ \\
LnTA (+/-) & -0.039 & -0.045 & 0.012 & 0.033 & -0.111 \\
& $(-0.49)$ & $(-0.58)$ & $(0.15)$ & $(0.42)$ & $(-1.41)$ \\
Turnover (+/-) & -0.084 & -0.114 & $-0.218^{* *}$ & -0.064 & $-0.165^{*}$ \\
Leverage (+/-) & $(-0.87)$ & $(-1.19)$ & $(-2.21)$ & $(-0.63)$ & $(-1.77)$ \\
FCF (+/-) & 0.430 & 0.388 & 0.490 & 0.486 & 0.496 \\
& $(1.09)$ & $(0.98)$ & $(1.26)$ & $(1.25)$ & $(1.23)$ \\
& $-0.829 * * *$ & $-0.864^{* * *}$ & $-0.802^{* *}$ & $-0.809^{* * *}$ & $-0.873^{* * *}$ \\
& $(-2.68)$ & $(-2.69)$ & $(-2.53)$ & $(-2.59)$ & $(-2.72)$ \\
& 0.298 & 0.275 & 0.386 & 0.354 & 0.319 \\
& $(1.26)$ & $(1.17)$ & $(1.63)$ & $(1.52)$ & $(1.33)$ \\
\hline & & & & $($ continued)
\end{tabular}


Table 5: Continued

\begin{tabular}{lccccc}
\hline SSP $=$ & IO & Option & OnLoan & InverseFee & SSDI \\
& $(1)$ & $(2)$ & $(3)$ & $(4)$ & $(5)$ \\
\cline { 2 - 6 } RelOfrSize (+/-) & $-0.329^{* * *}$ & $-0.277^{* * *}$ & $-0.264^{* * *}$ & $-0.275^{* * *}$ & $-0.322^{* * *}$ \\
& $(-3.24)$ & $(-2.97)$ & $(-2.87)$ & $(-2.98)$ & $(-3.21)$ \\
Sequence (+) & $0.877^{* * *}$ & $0.763^{* * *}$ & $0.846^{* * *}$ & $0.924^{* * *}$ & $0.736^{* * *}$ \\
& $(3.88)$ & $(3.33)$ & $(3.73)$ & $(4.13)$ & $(3.18)$ \\
Secondary (-) & $-1.950^{* * *}$ & $-1.931^{* * *}$ & $-1.954^{* * *}$ & $-1.989^{* * *}$ & $-1.876^{* * *}$ \\
& $(-9.47)$ & $(-9.38)$ & $(-9.55)$ & $(-9.80)$ & $(-8.94)$ \\
Pseudo R-sqr & 0.349 & 0.359 & 0.352 & 0.342 & 0.369 \\
$N$ & 1,859 & 1,877 & 1,873 & 1,873 & 1,855 \\
\hline
\end{tabular}




\section{Table 6: Analysis of abnormal short selling}

This table reports the results of an analysis examining SEOs with daily short-sales information. Panel A examines all SEOs with daily short-sales information. Panel B examines only SEOs with more than five trading days between their announcement and issue dates. We measure abnormal short selling (AbSS) as daily means or medians over the specific intervals, using three different benchmark periods. $(A D, I D)$ is the window from the announcement date through the issue date. The Appendix defines the variables. $p$-values for differences in means and medians between shelf and traditional offers are based on standard $t$-tests and Wilcoxon signed-rank tests. ${ }^{*}$, ${ }^{* *},{ }^{* * *}$ indicate significance at $10 \%, 5 \%$, and $1 \%$.

\begin{tabular}{|c|c|c|c|c|c|c|}
\hline & & & & & \multicolumn{2}{|c|}{ Differences } \\
\hline & \multicolumn{2}{|c|}{ Shelf offerings } & \multicolumn{2}{|c|}{ Traditional offerings } & \multirow{2}{*}{$\begin{array}{c}\text { Mean } \\
p \text {-value }\end{array}$} & \multirow{2}{*}{$\begin{array}{l}\text { Median } \\
p \text {-value }\end{array}$} \\
\hline & Mean & Median & Mean & Median & & \\
\hline \multicolumn{7}{|c|}{ Panel A: All SEOs } \\
\hline$A b S S 1(A D, I D)$ & -0.001 & -0.006 & $0.011 * *$ & $0.012 * * *$ & 0.056 & 0.001 \\
\hline$A b S S 2(A D, I D)$ & -0.001 & -0.005 & $0.016^{* * *}$ & $0.018 * * *$ & 0.004 & 0.000 \\
\hline$A b S S 3(A D, I D)$ & -0.002 & -0.006 & $0.018 * * *$ & $0.020 * * *$ & 0.001 & 0.000 \\
\hline$N$ & 768 & & 172 & & & \\
\hline \multicolumn{7}{|c|}{ Panel B: SEOs with more than five days between announcement and issuance } \\
\hline $\operatorname{AbSS1}(A D, I D)$ & 0.010 & 0.005 & $0.011 * *$ & $0.013 * * *$ & 0.925 & 0.574 \\
\hline$A b S S 2(A D, I D)$ & 0.011 & 0.003 & $0.016^{* * *}$ & $0.018 * * *$ & 0.503 & 0.321 \\
\hline$A b S S 3(A D, I D)$ & 0.009 & 0.000 & $0.018 * * *$ & $0.020 * * *$ & 0.241 & 0.114 \\
\hline$N$ & 135 & & 170 & & & \\
\hline
\end{tabular}




\section{Table 7: Analysis of the decision to complete shelf offerings within five days}

This table presents the results of tests of the impact of shelf equity issuers' short-selling potential (SSP) on their likelihood of completing an offering within five trading days versus more than five trading days. Panel A reports the results of a univariate comparison of the two subsamples of shelf issuers. $p$-values for differences in means and medians are based on standard $t$-tests and Wilcoxon signed-rank tests, respectively. Panel B reports logistic regression estimates. The dependent variable equals one for shelf offerings with less than or equal to five trading days between announcement and issuance and zero for shelf offerings with more than five trading days between announcement and issuance. The Appendix defines the explanatory variables. $t$-statistics are in parentheses. $N$ is the number of observations. ${ }^{* * *},{ }^{* * *}$ indicate significance at $10 \%, 5 \%$, and $1 \%$.

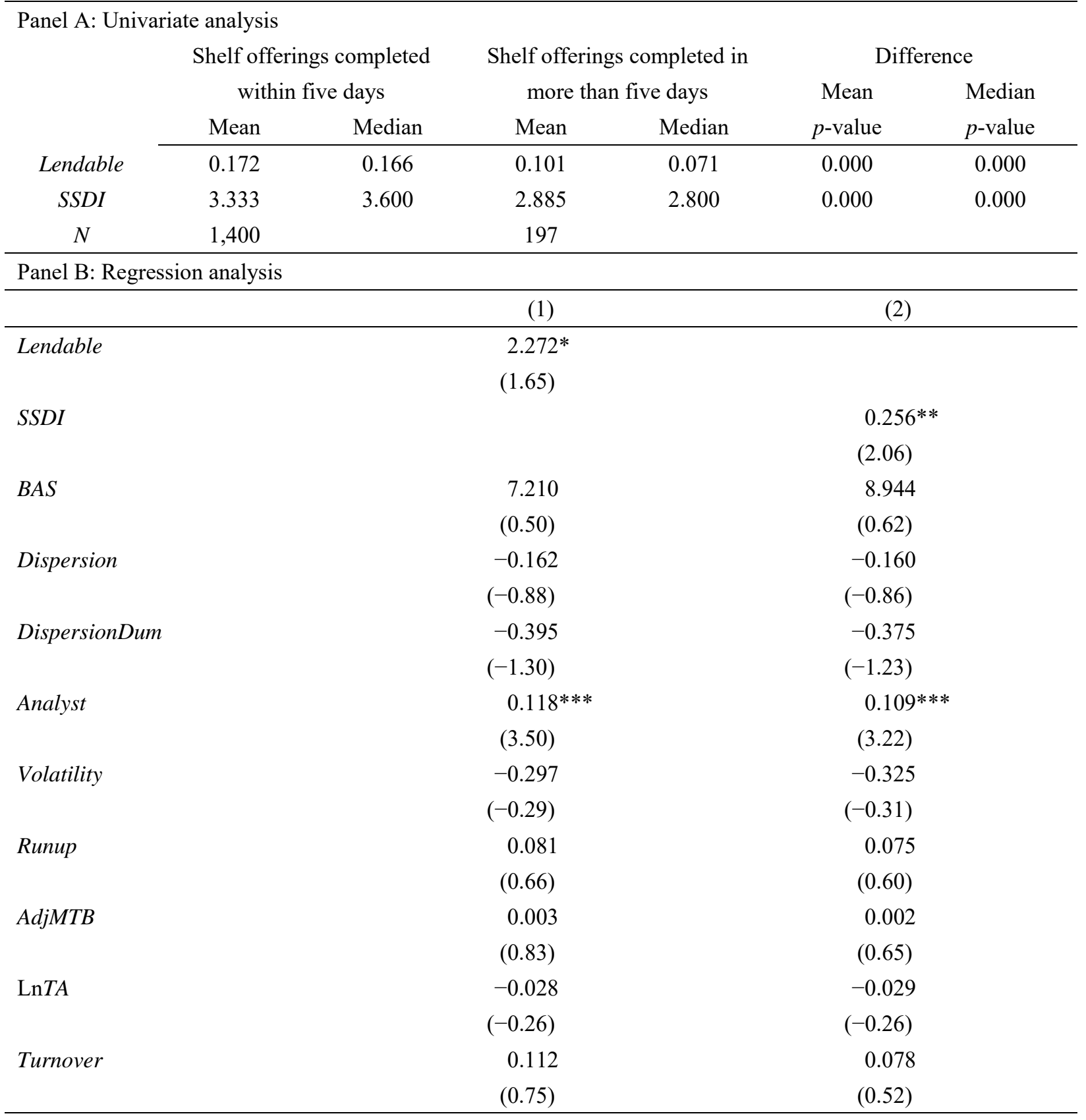


Table 7: Continued

\begin{tabular}{lcc}
\hline SSP $=$ & Lendable & SSDI \\
Leverage & $(1)$ & $(2)$ \\
\cline { 2 - 3 } FCF & 0.469 & 0.433 \\
& $(0.96)$ & $(0.88)$ \\
NYSE & $-0.763^{*}$ & -0.706 \\
& $(-1.65)$ & $(-1.53)$ \\
RelOfrSize & $0.769^{* *}$ & $0.729^{* *}$ \\
& $(2.47)$ & $(2.34)$ \\
Sequence & -0.101 & -0.003 \\
& $(-0.74)$ & $(-0.02)$ \\
Secondary & 0.326 & 0.286 \\
& $(1.45)$ & $(1.26)$ \\
Pseudo $R$-sqr & $-1.125^{* * *}$ & $-1.112^{* * *}$ \\
$N$ & $(-3.74)$ & $(-3.68)$ \\
& 0.386 & 0.379 \\
\hline
\end{tabular}




\section{Table 8: Analysis of offering discounts}

This table presents the results of an analysis of SEO offering discounts. We estimate a generalized two-stage model to control for the potential selection bias in the SEO method choice, with two discount equations in the second stage. The first stage is a probit regression modeling the determinants of the SEO method choice between shelf and traditional offerings presented in Table 3, column (1). Panel A reports estimation results for the second-stage discount equations, one for shelf offerings, the other for traditional offerings. The dependent variable is the offering discount. The Appendix defines the variables. $t$-statistics are in parentheses. $N$ is the number of observations. Panel B compares the mean of the actual discounts for shelf offerings with the mean of hypothetical offering discounts if shelf issuers had opted for a traditional offering instead. $p$-values for differences in means are based on standard $t$-tests. ${ }^{*},{ }^{* *},{ }^{* * *}$ indicate significance at $10 \%, 5 \%$, and $1 \%$.

Panel A: Regression analysis of offering discounts

\begin{tabular}{|c|c|c|}
\hline & Shelf offerings & Traditional offerings \\
\hline \multirow[t]{2}{*}{$\operatorname{LnTA}$} & -0.001 & 0.006 \\
\hline & $(-1.56)$ & $(0.85)$ \\
\hline \multirow[t]{2}{*}{ Volatility } & $0.021 * * *$ & 0.009 \\
\hline & $(4.02)$ & $(0.27)$ \\
\hline \multirow[t]{2}{*}{ RelOfrSize } & -0.000 & -0.001 \\
\hline & $(-0.00)$ & $(-0.09)$ \\
\hline \multirow[t]{2}{*}{ CARPos } & $0.014 * * *$ & $0.030 * *$ \\
\hline & $(5.89)$ & $(2.27)$ \\
\hline \multirow[t]{2}{*}{ LnPrice } & $-0.018 * * *$ & -0.010 \\
\hline & $(-8.94)$ & $(-0.70)$ \\
\hline \multirow[t]{2}{*}{ AdjMTB } & 0.000 & $-0.001 * * *$ \\
\hline & $(0.18)$ & $(-4.39)$ \\
\hline \multirow[t]{2}{*}{ Cluster } & $0.017 * * *$ & $0.039 * *$ \\
\hline & $(6.56)$ & $(2.14)$ \\
\hline \multirow[t]{2}{*}{ NYSE } & -0.004 & -0.028 \\
\hline & $(-1.22)$ & $(-1.53)$ \\
\hline \multirow[t]{2}{*}{ Lambda } & 0.010 & 0.005 \\
\hline & $(1.62)$ & $(0.41)$ \\
\hline$N$ & 1,597 & 280 \\
\hline
\end{tabular}

Panel B: Comparison of actual with counterfactual offering discounts for shelf offerings

\begin{tabular}{lccc} 
& Actual (\%) & Counterfactual (\%) & \multicolumn{2}{c}{ Difference } \\
& Mean & Mean & $p$-value \\
\cline { 2 - 4 } Shelf offerings & 4.678 & 5.283 & 0.001 \\
\hline
\end{tabular}




\section{Appendix: Variable definitions and sources}

This Appendix defines the variables in alphabetical order, with the data source in brackets at the end of each definition.

\begin{tabular}{|c|c|}
\hline Variable & Definition \\
\hline AbSS & $\begin{array}{l}\text { Abnormal short selling equal to the difference between relative short selling on day } t \text { and average } \\
\text { daily relative short selling during a benchmark period. Relative short selling is daily short sales } \\
\text { volume scaled by trading volume on the corresponding date. Benchmark period } 1(2,3) \text { is defined } \\
\text { as all trading days in the window from trading day }-60(-100,-200) \text { through day }-11 \text { relative to } \\
\text { the SEO announcement date. [TAQ Reg SHO (NYSE Short Sales), NASDAQ] }\end{array}$ \\
\hline AdjMTB & $\begin{array}{l}\text { Ratio of the market value to the book value of equity minus the median ratio in the issuer's industry } \\
\text { and offering year. Market and book values of equity are financial year-end figures for the latest year } \\
\text { before the SEO announcement. An issuer's industry is based on the Fama-French } 12 \text { industry } \\
\text { classification (Fama and French 1997). [Compustat] }\end{array}$ \\
\hline Analyst & $\begin{array}{l}\text { Natural logarithm of one plus the number of analysts following the firm for the year before the SEO } \\
\text { announcement. [Institutional Brokers' Estimate System }(\mathrm{I} / \mathrm{B} / \mathrm{E} / \mathrm{S})]\end{array}$ \\
\hline$B A S$ & $\begin{array}{l}\text { Bid-ask spread, equal to the average daily bid-ask spread as a percentage of stock price over the } \\
180 \text { trading days before the SEO announcement. [CRSP] }\end{array}$ \\
\hline CARPos & $\begin{array}{l}\text { Dummy variable equal to one if the cumulative abnormal return over the five days before the SEO } \\
\text { issue date is positive. [CRSP] }\end{array}$ \\
\hline Cluster & $\begin{array}{l}\text { Dummy variable equal to one if the decimal portion of the offer price is } 0.00,0.25,0.50 \text {, or } 0.75 \text {. } \\
\text { [SDC] }\end{array}$ \\
\hline Discount & Natural logarithm of the ratio of pre-offer-day closing price to the offer price. [CRSP, SDC] \\
\hline Dispersion & $\begin{array}{l}\text { Standard deviation of one-year-ahead analyst earnings-per-share forecasts in the month before the } \\
\text { SEO announcement divided by the mean estimate. }[\mathrm{I} / \mathrm{B} / \mathrm{E} / \mathrm{S}]\end{array}$ \\
\hline DispersionDum & $\begin{array}{l}\text { Dummy variable equal to one if analyst forecast dispersion data are unavailable and zero otherwise. } \\
{[\mathrm{I} / \mathrm{B} / \mathrm{E} / \mathrm{S}]}\end{array}$ \\
\hline FCF & $\begin{array}{l}\text { Ratio of free cash flow (operating income before depreciation minus interest expenses, income } \\
\text { taxes and capital expenditures) to total assets. All variables are financial year-end figures for the } \\
\text { year before the SEO announcement. [Compustat] }\end{array}$ \\
\hline Industry effect & $\begin{array}{l}\text { Dummy variables for different four digit SIC industries based on the Fama-French } 12 \text { industry } \\
\text { classification (Fama and French 1997). [Fama and French (1997)] }\end{array}$ \\
\hline InverseFee & $\begin{array}{l}\text { Quintile ranking of an offering based on inverse loan fees. Loan fee is the annual value-weighted } \\
\text { average fee, where the weights are proportional to the loaned amount of individual stock, measured } \\
\text { as the average loan fee in the three months ending one month before the SEO announcement. } \\
\text { [Markit] }\end{array}$ \\
\hline IO & $\begin{array}{l}\text { Number of shares held by institutions divided by shares outstanding at the end of the latest quarter } \\
\text { before the SEO announcement date and capped at one. [Thomson Reuters' CDA/Spectrum } \\
\text { Institutional (13f) Holdings] }\end{array}$ \\
\hline Lambda & $\begin{array}{l}\text { Inverse Mills ratio, equal to } \phi\left(\gamma \boldsymbol{Z}_{i}\right) / \Phi\left(\gamma \boldsymbol{Z}_{i}\right) \text { for the shelf SEO discount equation, and } \\
-\phi\left(\gamma \boldsymbol{Z}_{i}\right) /\left[1-\Phi\left(\gamma \boldsymbol{Z}_{i}\right)\right] \text { for the traditional SEO discount equation. } \boldsymbol{Z}_{i} \text { and } \gamma \text { are the independent } \\
\text { variables and coefficients estimated from the first stage regression. } \phi \text { and } \Phi \text { are the normal density } \\
\text { and cumulative distribution functions. }\end{array}$ \\
\hline
\end{tabular}


Appendix: Continued

Lendable Average lending supply in the three months ending one month before the SEO announcement date. Lending supply is the dollar value of shares available for lending on a given day scaled by a firm's market capitalization on that day. [Markit]

Leverage Ratio of long-term debt to total assets. Long-term debt and total assets are financial year-end figures for the year ending before the SEO announcement. [Compustat]

LnPrice Natural logarithm of the firm's stock price the day before the SEO announcement. [CRSP]

LnTA

NYSE

OnLoan Natural logarithm of the firm's total assets. Total assets are financial year-end figures for the year ending before the SEO announcement. [Compustat]

Dummy variable equal to one if an issuer's stock is listed on NYSE and zero otherwise. [CRSP]

Average loan quantity in the three months ending one month before the SEO announcement date. Loan quantity is the dollar value of shares on loan on a given day relative to market capitalization. [Markit]

Option Put options outstanding, measured as a dummy variable equal to one if the issuers' stock has put options outstanding in the three months ending one month before the SEO announcement, and equal to zero otherwise. [Option Metrics]

Pilot firm Dummy variable equal to one if the firm is a pilot firm in the pilot program under Regulation SHO. [SEC]

Pilot period Dummy variable equal to one for the period from May 2005 to June 2007, in which the SEC implemented its pilot program under Regulation SHO. [SEC]

RelOfrSize Ratio of offering proceeds to the firm's total assets. Total assets are financial year-end figures for the year ending before the SEO announcement. [Compustat, SDC]

Rule2007 Dummy variable equal to one if the offering takes place after the implementation of the 2007 SEC regulatory amendment in Rule 105. [SEC]

Runup Buy-and-hold abnormal return over the 180 trading days before the announcement net of the CRSP value-weighted market return. [CRSP]

Secondary Dummy variable equal to one for SEOs including a secondary component, and zero otherwise. [SDC]

Sequence Dummy variable equal to one for the third or later SEO since the firm's IPO, and zero otherwise. [SDC]

SSDI Short-selling determinants index, measured as the average quintile ranking of an offering based on individual short-selling potential proxies (Lendable, IO, Option, OnLoan, and InverseFee). [Markit, Thomson Reuters' CDA/Spectrum Institutional (13f) Holdings, Option Metrics]

Turnover Average trading volume as a percentage of shares outstanding over the 180 trading days before the SEO announcement date. [CRSP]

Volatility Annualized stock return volatility, calculated from daily stock returns over the 180 trading days before the SEO announcement date. [CRSP] 


\section{Internet Appendix for}

Shelf versus traditional seasoned equity offerings: The impact of potential short selling

This Appendix describes SEC regulations relating to shelf registration (Table IA1), short-sale constraints prior to security offerings (Table IA2), and short-sale constraints for exchange-listed stocks in general (Table IA3), in chronological order. We only mention rules and amendments relevant to our sample offerings. We retrieve this information from the SEC website (www.sec.gov) and academic papers. 


\begin{tabular}{|c|c|c|}
\hline Rule & Date & Summary \\
\hline Rule 415 & 1982 & $\begin{array}{l}\text { Rule } 415 \text { establishes that eligible firms can file one shelf security registration statement every two } \\
\text { years, without having to disclose detailed information about the actual amount, timing, or expected } \\
\text { use of proceeds of security offerings. A U.S. firm is eligible to offer seasoned equity through a shelf } \\
\text { registration only if it is eligible to use Form S-3 (Autore et al. 2008), that is if it: } \\
\text { 1. has a public float higher than a stipulated minimum of } \$ 150 \text { million, based on a stock price } \\
\text { within } 60 \text { days of filing the shelf offering; } \\
\text { 2. has not failed to pay dividends or sinking fund instalments on preferred stock or defaulted on } \\
\text { instalments on indebtedness for borrowed money or on material leases since the end of the last } \\
\text { year covered by its audited financial statements; } \\
\text { 3. has been subject to the reporting requirements of the Exchange Act for at least } 12 \text { calendar } \\
\text { months immediately preceding the filing of the registration statement and has filed all required } \\
\text { reports on time with the SEC during that period; } \\
\text { 4. has securities traded under the } 1934 \text { Exchange Act (or is required to file reports under the } \\
\text { Exchange Act). }\end{array}$ \\
\hline Amendment to Rule 415 & October 1992 & $\begin{array}{l}\text { The SEC amends Rule } 415 \text { as follows. Firms can register debt, equity, and other securities in a single } \\
\text { 'universal' shelf registration statement, without disclosing the type of securities until the issue date. } \\
\text { In addition, the SEC reduces the public float threshold to qualify for shelf registrations to } \$ 75 \text { million } \\
\text { (Federal Register 1992). }\end{array}$ \\
\hline Further amendment to Rule 415 & December 2005 & $\begin{array}{l}\text { The SEC eliminates the two-year limitation. A shelf registration statement now applies for three } \\
\text { years. }\end{array}$ \\
\hline Further amendment to Rule 415 & December 2007 & $\begin{array}{l}\text { The SEC allows firms with a public float below } \$ 75 \text { million to use Form S-3 (and therefore be shelf } \\
\text { eligible) if they: } \\
\text { 1. do not sell in a } 12 \text {-month period before the filing of the Form more than the equivalent of } \\
\text { one-third of their public float (often labelled the 'one-third cap' requirement); } \\
\text { 2. are not and have not been shell companies for at least } 12 \text { months prior to the filing of the Form; } \\
\text { 3. meet all of the other eligibility requirements for using the Form (SEC } 2007 \mathrm{~b} \text {; SEC 2017b). }\end{array}$ \\
\hline
\end{tabular}


Table IA2: Short-sale constraints prior to public security offerings

\begin{tabular}{|c|c|c|}
\hline Rule & Date & Summary \\
\hline Rule $10 b-21$ & August 1988 & $\begin{array}{l}\text { This rule prohibits investors who short shares any time between the filing and issue dates of a public } \\
\text { security offering from covering their positions with securities purchased in the offering. }\end{array}$ \\
\hline Rule 105 & April 1997 & $\begin{array}{l}\text { This rule prohibits investors from covering short sales made within five trading days of an offering } \\
\text { with shares purchased in the offering. The rule applies only to traditional offerings. It relaxes Rule } \\
10 \mathrm{~b}-21 \text { by only preventing covering transactions in a restricted period before the issue date rather } \\
\text { than in the much longer period between the filing and issue dates. }\end{array}$ \\
\hline Amendment to Rule 105 & September 2004 & This amendment extends Rule 105 to shelf offerings. \\
\hline Further amendment to Rule 105 & October 2007 & $\begin{array}{l}\text { This amendment to Rule } 105 \text { prohibits anyone who shorts in the restricted period of five trading days } \\
\text { before the issue date from buying shares in the offering. The change is aimed at investors using } \\
\text { cross-trading strategies to avoid the constraints imposed by the original Rule } 105 \text { (Autore and Gehy } \\
2013 \text { ). The amendment includes an exemption allowing restricted-period short sellers to purchase } \\
\text { SEO shares if they cover their short positions at least one trading day before the pricing of the } \\
\text { offering (Autore and Gehy 2013). }\end{array}$ \\
\hline
\end{tabular}




\section{Table IA3: General short-sale constraints}

\begin{tabular}{|c|c|c|}
\hline Rule & Date & Summary \\
\hline $\begin{array}{l}\text { Pilot program under Rule } 202 \mathrm{~T} \text { of } \\
\text { Regulation SHO }\end{array}$ & May 2005 & $\begin{array}{l}\text { As part of its Regulation SHO, which aims to update short-sale regulations, the SEC adopts a pilot } \\
\text { program relaxing short-selling restrictions by removing short-sale price test rules for a } \\
\text { randomly-selected subsample. The subsample consists of one-third of Russell } 3000 \text { stocks. The pilot } \\
\text { program runs from May 2, } 2005 \text { to July } 6,2007 \text { (extended from April, 2006) (SEC 2005). }\end{array}$ \\
\hline $\begin{array}{l}\text { General removal of short-selling } \\
\text { restrictions }\end{array}$ & July 2007 & $\begin{array}{l}\text { The SEC exempts all exchange-listed stocks, including stocks not involved in the pilot program, from } \\
\text { short-sale price test rules (SEC 2007a; Fang 2016). }\end{array}$ \\
\hline $\begin{array}{l}\text { Re-establishment of short-selling } \\
\text { restrictions }\end{array}$ & February 2010 & $\begin{array}{l}\text { The SEC partially restores a modified uptick rule. Under the new rule, price tests are triggered when } \\
\text { a security's price declines by ten percent or more from the previous trading day's closing price (Fang } \\
\text { 2016). }\end{array}$ \\
\hline
\end{tabular}

